\title{
Research
}

\section{The Relevance of Local Participatory Scenario Planning for Ecosystem Management Policies in the Basque Country, Northern Spain}

\author{
Igone Palacios-Agundez $^{1}$, Izaskun Casado-Arzuaga ${ }^{1}, \underline{\text { Iosu Madariaga }}^{1,2}$ and Miren Onaindia $^{l}$
}

ABSTRACT. As part of the Millennium Ecosystem Assessment in Biscay, Basque Country, we described scenarios for Biscay through 2050 in an integrated and participatory way by downscaling the Millennium Ecosystem Assessment (MA) global scenarios, analyzed how ecosystem services and human well-being might change in a range of plausible futures, identified management strategies for the territory through a backcasting process, and explored the relevance of scenarios to policy making. Our intention was to strengthen the link to policy making and to achieve a real implementation of our research results in ecosystem management policies. We also aimed to provide more insights on how large-scale scenario developments can be translated to the local level. In doing so, we emphasized specific local characteristics and used highly participatory methods focusing on novel elements, such as organizing back-to-back workshops, creating coherent scenarios across scales, using visual elements to present exploratory scenarios, and combining exploratory scenarios with normative backcasting using a World Café methodology. The outcome scenarios and management proposals are relevant for decision making and planning processes at local scale and at the same time, they are comparable to other assessment scenarios. This local participatory scenario process and tool for landscape planning is already having a policy impact thanks to the involvement of public administration technicians and policy makers. In the recently renewed strategic policy plan for sustainability of the county, this assessment is considered a high priority. Therefore, for the next steps of the assessment, detailed guidelines for ecosystem management policies are planned.

Key Words: Biscay subglobal assessment (EEMBiscay); ecosystem service; Millennium Ecosystem Assessment; multiscale scenarios; policy impact; scenario planning; stakeholder participation

\section{INTRODUCTION}

Scenario exercises are particularly useful in assessing future developments within complex and uncertain systems, such as ecosystems (Henrich et al. 2010). By envisioning alternative futures, scenarios can help decision makers identify ecosystem management policies that will promote desired outcomes or characteristics, such as ecosystem resilience (Shearer 2005, Carpenter and Folke 2006, Biggs et al. 2007). Scenario planning allows the construction of proactive strategies to adapt management to possible future events (Huss 1988, Wollenberg et al. 2000) and also improves adaptive capacity (Biggs et al. 2007). Thus, decisions based on scenarios provide greater resilience (Peterson et al. 2003) and allow a relevant social-ecological management.

It is widely recognized that the involvement of affected communities is needed to achieve sustainable management of natural resources (Ribot 2002, Pretty 2003), especially at local scales (Gunderson et al. 1995, Berkes and Davidson-Hunt 2006). In fact, involving local actors in decision-making processes will result in more sustainable social-ecological systems (Schultz et al. 2007). Thus, integrated and participatory approaches in scenario planning can be a useful and powerful tool to facilitate sustainable landscape management because such approaches draw on multiple sources of knowledge to accurately describe complex socialecological processes (Whitfield et al. 2011) and because stakeholder participation can yield more effective and resilient decisions (Reed 2008).

Some studies have highlighted the importance of landscapelevel assessments to reinforce civic engagement (Brunckhorst et al. 2006) and enable collaborative decision-making processes (Termorshuizen and Opdam 2009) to create a sustainable future. In the current context of scientific, social, and policy concerns regarding conditions, trends, trade-offs, and the future of ecosystem services and human well-being at the international, national, and local scales, e.g., the Millennium Ecosystem Assessment (MA; MA 2003, 2005a), its follow-up program through the Sub-Global Assessment Network (SGA Network 2011), and the Intergovernmental Science-Policy Platform on Biodiversity and Ecosystem Services (IPBES; Perrings et al. 2011), there is a specific need to explore landscape development processes, as well as response options based on collaborative decision-making processes at local scales. Furthermore, strengthening the link to policy making remains a historical weakness of the MA. Through the landscape scale this link between science and policy making may be studied in greater detail and perhaps be strengthened.

Scenarios provide a very useful tool to address cross-scale feedback and facilitate multiscale discussions (Zurek and Henrichs, 2007). For this reason, the local, regional, or global 
scenario development exercises of the Millennium Ecosystem Assessment (Lebel et al. 2005, MA 2005b) aimed to assess the consequences of ecosystem change for human well-being at multiple scales. In fact, subglobal use of global scenarios could test methods for scaling down scenarios and provide regional calibration of the global scenarios (Lebel et al. 2005). However, from all the subglobal assessments that developed scenarios during the MA process, only in the case of the Southern Africa Millennium Ecosystem Assessment (SAfMA), the Caribbean Sea, and the Portugal assessments was a substantive link maintained between global and subglobal scenarios (Lebel et al. 2005). The Sub-Global Scenarios Working Group (Lebel et al. 2005) detected a need for understanding how large-scale developments could be translated to the local level to face the challenge of linking global and subglobal scenarios.

In this part of the Millennium Ecosystem Assessment in Biscay subglobal assessment (EEMBiscay 2012), we described scenarios for Biscay through 2050 in an integrated and participatory way by downscaling MA global scenarios (MA $2005 b$ ), analyzed how ecosystem services and human wellbeing might change in a range of plausible futures, identified management strategies for the territory through a backcasting process, and explored the relevance of scenarios to policy making. Our purpose is to strengthen the link to policy making and to achieve a real implementation of the research results in ecosystem management policies. In fact, several public administration technicians and policymakers are involved in our research, and they demand this scenario planning process as a tool for adaptive management. We focus on two specific objectives: first, we aim to describe, focusing on novel elements, scenarios at local scale as a process and tool for landscape planning, create buy-in to the EEMBiscay assessment process, and explore possible responses to improve ecosystem management and thus human well-being. Second, we aim to provide more insights on how large-scale scenario developments can be translated to the local level. To this end, we discuss the scale issue and a summary of lessons learned from the experiences of this subglobal assessment scenario exercise, which may be of particular interest for ongoing and future ecosystem assessments.

\section{BISCAY SOCIAL-ECOLOGICAL SYSTEM}

Biscay, the capital of which is Bilbao, is located in the north of the Iberian Peninsula $\left(43^{\circ} 07^{\prime} \mathrm{N}, 2^{\circ} 51^{\prime} \mathrm{W}\right)$, in the Basque Country (Fig. 1). It has an area of $2217 \mathrm{~km}^{2}$ and a population of 1,153,351 inhabitants (Eustat 2013). This high population density, focused in the river estuaries, is a consequence of the heavy industrialization that Biscay underwent throughout the nineteenth and early twentieth centuries. Important ecosystems degradation and severe environmental problems followed this industrialization process, e.g., air pollution and river contamination. This iron-based economic development characterized the social and economic development of the region until the beginning of the 1990s when an economic crisis hit Spain. Afterward, Biscay underwent a process of profound transformation. The industry sector evolved toward what is known as neoindustry and the service sector was clearly strengthened. During this process, research and technological centers have been promoted, as well as environmental education. Several environmental problems related to heavy industry were also faced. Basque institutions have since been working to reinforce environmental measures and toward sustainable development in the region (www.bizkaia21.net).

Fig. 1. Map of the study area: Biscay in relation to Europe.

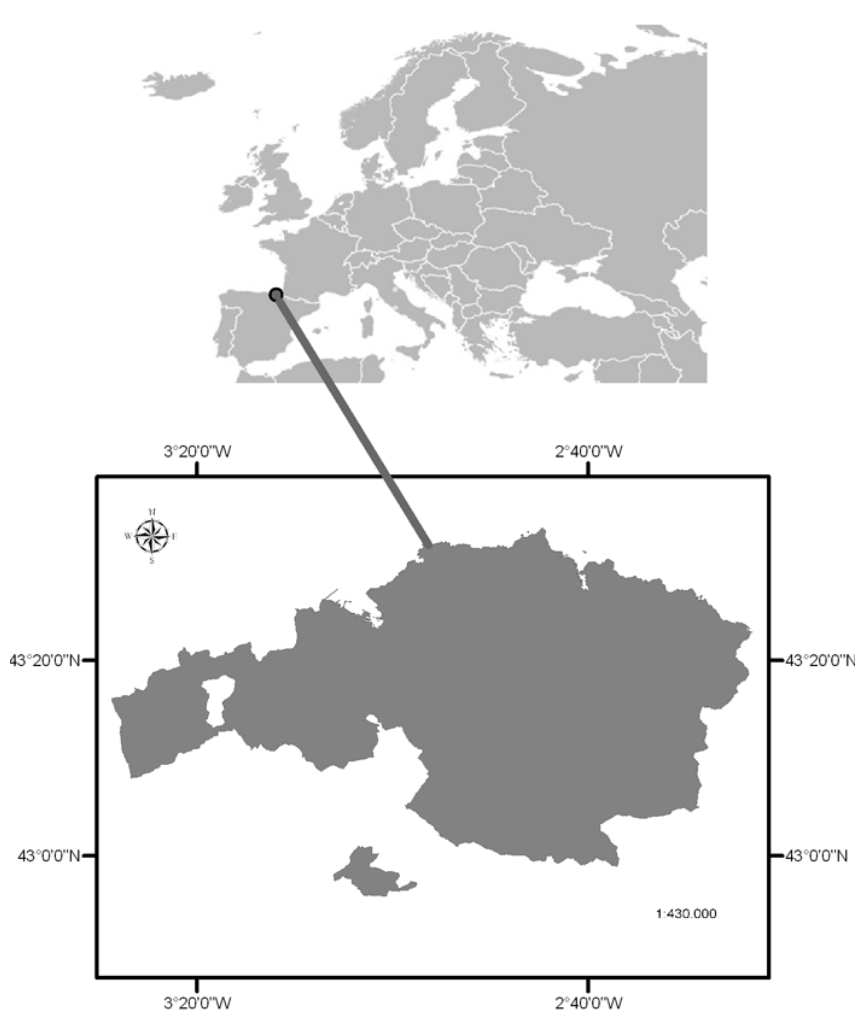

The primary sector, which includes agriculture, forestry, and fishing, has also suffered an important transformation process during the last decades. The industrialization period entailed high rural land abandonment. To face the rural crisis, reforestation with exotic species was promoted (Groome 1990, Madariaga et al. 2011). Currently $57 \%$ of the land is covered by forest systems of which $79 \%$ are exotic forest plantations, mainly coniferous (Basque Government 2005), and the management techniques used are quite aggressive (Olarieta et al. 1999, Merino et al. 2004). These monoculture plantations of fast-growing exotic species, together with their typical forms of management, are associated with a series of environmental problems, such as soil erosion, soil compaction, 
nutrient loss, turbidity and supply of surface water, and biodiversity loss (Amezaga and Onaindia 1997, Olarieta et al. 1999, Merino et al. 2004, Santos et al. 2006, Leslie et al. 2012).

Basque people have historically been linked to the land and its services. Currently, both socially and culturally, these links are still highly valued. However, the primary sector is facing a challenging economic situation and currently it only covers a small portion, $0.6 \%$, of the total gross added value (Eustat 2011), and rural areas are more and more like small cities with an important service sector and connected by big infrastructures. Thus, strategic planning to create sustainable landscapes is needed, as well as opportunities to discuss a new rural-urban relationship.

\section{METHODS}

The combining of different participative methods has been recommended for the management of social-ecological systems (Stringer et al. 2006, Lynam et al. 2007) and has already been successfully applied (Jessel and Jacobs 2005, Pereira et al. 2005, Patel et al. 2007, Palomo et al. 2011). To describe scenarios for Biscay and explore their policy relevance, we used a combination of highly participatory methods focusing on novel elements, such as organizing backto-back workshops, creating coherent scenarios across scales, using visual elements to present exploratory scenarios, or combining exploratory scenarios with normative backcasting using a World Café methodology (Brown and Isaacs 2005). We also emphasized specific local characteristics, although large-scale external drivers may be important, local scenarios should be based as much as possible on local conditions (Kok et al. 2007).

Data were collected from structured questionnaires and workshops held after a stakeholder selection process. The structured questionnaires were administered before the workshops, between May and mid-June 2010. The workshops were held in Bilbao for two consecutive days, on the 17th and 18th of June 2010, for approximately eight hours each day (see Appendix 1 for detailed agenda). Our reasoning when organizing two workshops back-to-back was to ensure strong continuity between both days and make it easier for stakeholders to participate in the whole process. This saved time and made the overall process cheaper.

This participatory methodology consisted of six phases: (1) identification of key stakeholders; (2) definition of the importance of ecosystem services and the potential for successful intervention through structured questionnaires administered before the workshops; (3) identification of key drivers of change, beginning with the results of the questionnaires; (4) description of local participatory scenarios for Biscay by downscaling MA global scenarios; (5) characterization of scenarios in terms of the provision of ecosystem services and human well-being; and (6) selection and description of the target scenario and definition of management strategies for Biscay. The overall process enabled us to explore how the link to policy making may be strengthened.

\section{Identification of key stakeholders}

Stakeholder selection is crucial for the outcome of any participatory process (Wollenberg et al. 2000, Kok et al. 2007). It has been suggested that at least four groups of stakeholders should be represented: policy makers, business representatives, citizens, and experts (Andersen and Jaeger 1999, van Asselt and Rijkens-Klomp 2002). Recent successful participatory scenario development processes have been carried out with a wider variety of stakeholders (Scholes and Biggs 2004, Kok et al. 2006a,b, 2007, Patel et al. 2007, Palomo et al. 2011). To enable this broad participation, we carried out a precise process of stakeholder selection and involvement. The research team's previous knowledge of the Biscay social-ecological system and previous work with stakeholders through surveys and workshops within the Millennium Ecosystem Assessment in Biscay subglobal assessment (EEMBiscay) proved useful in this stakeholder selection and involvement process (Madariaga et al. 2010, EEMBiscay 2012, Palacios et al. 2012). We were successful in engaging stakeholders at the local level in the workshops. A total of 39 people of a wide range of age, professions, and fields of interest took part in the workshops; $59 \%$ of the participants were women. The participants included public administration technicians and policymakers, researchers and experts in different areas, e.g., architecture, economics, biology, geology, engineering, teaching, and journalism, personnel from environmental associations and NGOs, environmental education professionals, and representatives of agriculture, i.e., the farmers' union, the forestry sector, i.e., a cluster of private forest land owners, and the private sector. Most participants were satisfied with their own role in the group process and expressed interest in taking part in a follow-up workshop (Table A2.1 in Appendix 2).

\section{Defining the importance and potential for successful intervention in ecosystem services}

Before the workshops, we administered a survey to provide data for the workshop to optimize the results of the working groups. Concretely, we designed a structured questionnaire to help us identify the most important ecosystem services to address and to provide a starting point to identify key drivers of change. As a novel element, the questionnaire included a ranking of different ecosystem services by their importance, from 1 to 4 , where 1 was the most important, and potential for successful intervention, from 1 to 4 , where 1 indicated the highest potential for successful intervention. The same was performed for direct and indirect drivers. The inclusion of a ranking of potential for successful intervention enabled the exploration of policy impact and facilitated identifying management priorities. A total of 35 stakeholders completed the questionnaire. 


\section{Identification of key drivers of change}

Beginning with the results of questionnaires administered before the workshops (see Figs. A2.1, A2.2 in Appendix 2), key drivers of change were identified in the first day participatory workshop. In the workshop, the participants were divided into 4 heterogeneous groups of approximately 10 participants, following the general recommendations for scenario workshop development given by Heemskerk (2003). Because good facilitation is key to the success of workshops (Shuman 1996, Hjorts $\varnothing 2004$ ), we ensured that every subgroup included at least one representative of the research group and an experienced local facilitator. Participants discussed the key drivers of change in the Biscay social-ecological system. Then, in a plenary session, each group presented a consensus list of the direct and indirect drivers of change that they considered to be the most relevant. After the findings of the working groups were discussed in the plenary meeting, a final common list of drivers of change was developed by general consensus.

\section{Description of local participatory scenarios for Biscay by downscaling Millennium Ecosystem Assessment (MA) global scenarios}

Once the main drivers of change were defined, participants were asked to describe scenarios for Biscay by downscaling the global-scale Millennium Ecosystem Assessment scenarios to the local level; linking multiple scales introduces a greater appreciation of the interconnectivity of processes and people operating at different scales (Kok et al. 2007). The four global scenarios, i.e., Order from Strength, Global Orchestration, Techno Garden, and Adapting Mosaic (Cork et al. 2005), which were linked to quantitative models, explored two global-development paths. One of the paths had the world become increasingly globalized, and in the other path, the world becomes increasingly regionalized. The four scenarios also explored two different approaches to ecosystem management, one in which actions are reactive and most problems are addressed only after they become obvious, and one in which ecosystem management is proactive and policies deliberately seek to maintain ecosystem services for the long term (MA 2005b). Unlike SAfMA and other subglobal assessments (Biggs et al. 2004, Scholes and Biggs 2004, Lebel et al. 2005), at the time we carried out our scenario exercise, MA global scenarios were already available. This allowed a consecutive scenario development process, which is a coupling type that had the advantage that the follow-up process began from a clear starting point, and the derivative scenarios could therefore be developed with the desired consistency among them (Zurek and Henrichs 2007). With the flexible use of a higher level framework, creativity and ownership at lower levels can be encouraged without losing the cross-scale connections (Kok et al. 2007). To downscale MA global scenarios, we used a coherent linkage across scales, which allowed regional or local deviation where needed (Zurek and Henrichs 2007). We opted for coherent scenarios across scales because while maintaining cross-scale connections, local variability can be included and therefore, the resulting scenarios are useful for decision making and planning processes at local scales. This allowed for the exploration of the relevance of scenarios to policy making. The link consisted of explaining the MA global scenario and asking participants to describe how the Biscay social-ecological system would evolve from the present to 2050 under a given scenario. The methods and approaches used to explain the MA global scenarios were visual, i.e., each scenario was presented in a poster that showed its main characteristics with an image summarizing it. The visual presentation of scenarios is a novel element that we used through the different phases of the scenario description process to ensure a common and widespread understanding among participants. Also, when required, additional information was given by the facilitators. Participants described the chain of events and the end points among the scenarios taking into account the main drivers of change previously selected. Finally, participants prepared a presentation focusing on the storyline and main characteristics. Participants highlighted some of the major differences between the MA global scenario and the Biscay scenario linked to it. Participants were contacted after the workshop and asked to choose their favorite name for the scenario on which they had worked.

\section{Scenario characterization in terms of the provision of ecosystem services and human well-being}

Participants then characterized the scenarios in terms of the provision of ecosystem services and human well-being. To this end, 20 ecosystem services were chosen from the structured questionnaires administered before the scenario workshop as well as from previous work of the EEMBiscay assessment (Casado-Arzuaga et al. 2013), along with various indicators of human well-being, i.e., basic material needs, health, good social relationships, security and freedom of choice, education, equity, employment, and fossil-fuel consumption (Narayan et al. 1999, Butler et al. 2003). The characterization of scenarios involved both individual opinions and group discussion. In the first stage of the analysis, each participant completed a table in which he or she decided whether each ecosystem service and social variable would grow, fall, or remain constant. Then, the tables were discussed and consensus tables were written. This methodology allowed us to achieve a relatively rapid consensus among all participants. Every opinion was weighed equally.

\section{Target scenario selection and description and definition of management strategies}

One of the key objectives in developing participatory scenarios is to involve policymakers and other stakeholders and thus to more directly influence long-term planning processes (Kok et al. 2007). To this end, backcasting, defined as generating a desirable future, and then looking backward from that future to the present to strategize and to plan how it could be achieved 
(Quist and Vergragt 2006, Quist 2007), has gradually become more popular and more widely applied over the last decade (Vergragt and Quist 2011). Moreover, it is conceptually appealing, methodologically feasible, and practically useful to combine exploratory scenario development and backcasting analysis (Kok et al.2011). The aim of the second day workshop was to seek policy guidelines that could lead to a desirable future for the Biscay social-ecological system. For this reason, we carried out a participatory backcasting exercise taking into account the learning of the first day workshop.

The morning session started with a plenary presentation of the scenarios' characterization results from the previous day workshop. The comparison among scenarios was made in a very visual way, using murals with arrows that showed trends in ecosystem services. This visual presentation of the exploratory scenario results allowed a straight comparison among scenarios and facilitated group discussion and consensus building. In fact, this innovative element showed graphically where the focus of attention should be placed. Participants discussed the desired and undesired aspects for the future and extracted the most positive elements of each scenario. Afterward, participants created, through general consensus, the target scenario for the Biscay social-ecological system.

Once the target scenario had been selected and described, we instituted a 'World Café' (Brown and Isaacs 2005) to define management strategies that would achieve the desirable future. The World Café is a powerful social technology for engaging people in conversations that matter (The World Café 2012). The World Café methodology can be used to access the collective intelligence and best thinking of any group, increasing people's capacity for effective action in pursuit of common aims (Brown and Isaacs 2005). We worked on four different conversation tables, each of which centered on a type of ecosystem service or on variables related to human wellbeing. After a 20-minute round of conversation, participants were invited to change tables randomly. One host stayed at each table to share with the new arrivals the key insights and management proposals that emerged from the prior dialogue. This process was repeated for three more rounds, so each of the analyzed subjects was enriched with a wide range of knowledge and experiences. The process was followed by a harvesting of the dialogue to which all participants contributed. To our knowledge to date, this is the first subglobal assessment that uses a World Café methodology in a backcasting process.

\section{RESULTS}

\section{Importance of ecosystem services and the potential for successful intervention}

To identify the most critical ecosystem services, we considered their importance and the potential for successful intervention in the Biscay social-ecological system according to the questionnaires (Fig. 2). The ecosystem services located in the upper right of Figure 2 were given highest priority because they were ranked highest in importance and potential for successful intervention by the greatest number of respondents. The high-priority services extracted were airquality regulation, water regulation, biodiversity, environmental education, traditional knowledge, increases in scientific knowledge, and water supply. Among these services, air quality was considered most important, i.e., 74.29\% of respondents assigned it the highest value, and environmental education was considered the service that had the highest potential for successful intervention because $51.43 \%$ of respondents assigned it the highest value. With regards to cultural, regulating, and provisioning services, cultural services were considered by far to have the highest potential for successful intervention, whereas in some provisioning services, like in the case of energy supply, the limitations to decide on them from the local scale were recognized.

\section{Drivers of change}

The compiled consensus list of the most relevant indirect drivers of change contained: (1) global demographic trends; (2) changes in production and consumption patterns; (3) education and knowledge sharing; (4) development of the industrial, construction, and service sectors; (5) development of the primary sector; (6) participatory policy making, governance, and institutional coherence; and, (7) innovation, science, and the pace of technological change. Participants posited that all direct drivers were related and compiled the following consensus list of the most relevant direct drivers of change: (1) water, air and biotic pollution, soil contamination, and climate change; (2) ecosystem degradation, river alteration, and transformations in agriculture; (3) intensive forest management; and (4) land and urban planning. In this case, land use and urban planning were highlighted as drivers of change, in a construction that included urbanization and infrastructural development. In both the questionnaire and the workshops, participants recognized forest management as an important driver.

\section{Future scenarios for Biscay, 2050}

The four scenarios described by participants during the scenario-planning process are presented with brief storylines. Table 1 describes the key indirect and direct drivers of each scenario as well as current conditions to compare the scenarios with the present day. These outcome scenarios of the Biscay subglobal assessment are named EEMBiscay scenarios.

Oppressed Biscay, adapted from Order From Strength In this scenario, decisions are made by a repressive and totalitarian government. Social participation is diminished by media manipulation and the influence of multinational corporations. Social exclusion and marginalization increases. Tendencies toward individualism and mercantilism increase, 
Fig. 2. Scatter plot of the importance of ecosystem services of Biscay social ecological system and potential for successful intervention, according to the respondents. The $\mathrm{X}$ axes represent the percentages of respondents that consider each ecosystem service of the highest importance of the ranking (1 out of 4); whereas the Y axes represent the percentages of respondents that consider each ecosystem service with the highest potential for successful intervention (1 out of 4). Name codes: Env Educ $=$ Environmental education, Trad Know $=$ Traditional knowledge, Local Id $=$ Local identity, Rec Act $=$ Recreational activities, Aest \& Spirit = Aesthetic and spiritual values, Scientific Knowl = Increases in scientific knowledge, Water reg = Water regulation, Biodiver $=$ Biodiversity, Morph-sed reg $=$ Morpho-sedimentary regulation, $\mathrm{C}$ storage $=$ Carbon storage, Soil \& nutri reg $=$ Soil and nutrient regulation, Climate reg $=$ climate regulation, Distur mit $=$ disturbance mitigation, Biotic mat $=$ biotic matirials, Abiotic mat $=$ Abiotic materials.

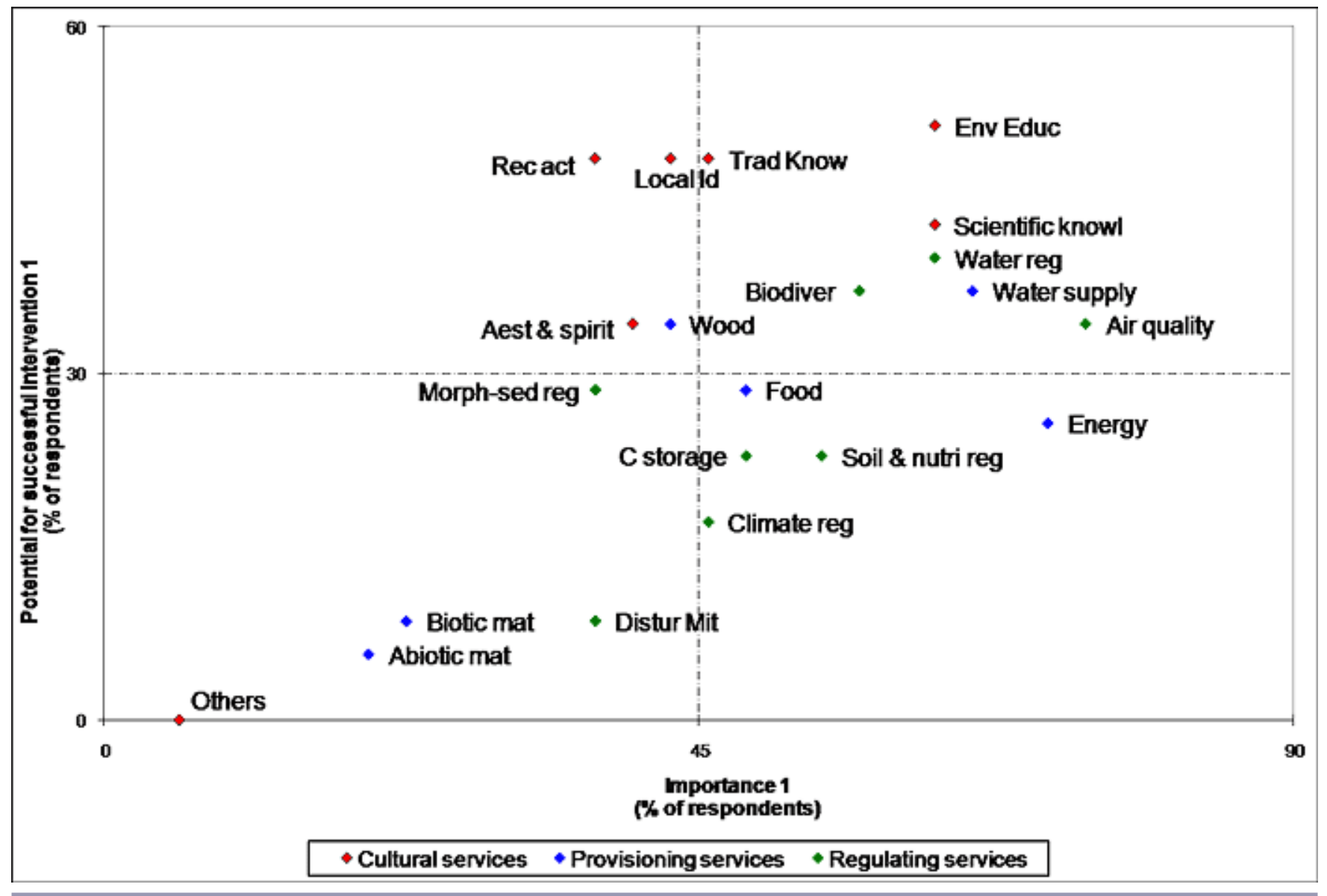

and consumption remains highly delocalized with a high rate of importation of energy, food, and raw materials. Following a productivity crisis and land abandonment, the primary sector converts into a tertiary tourism sector. Tourism is elitist, based on good quality and high prices, and leans on strongly protected, isolated natural areas that do not, however, guarantee biodiversity conservation. Growing unrest and social conflicts prompt the emergence of alternative movements and resistance minority groups.

\section{Global Delicatessen, adapted from Global Orchestration} Decisions are made in a global and reactive way, but interconnectivity and social networks reinforce civil society and participation. Local institutions lose power to global institutions, generating more uniformity among institutions. Biscay specializes in elitist, local agroecological products that the great majority of inhabitants cannot afford; so most people consume imported, transgenic products. The landscape is preserved because it is closely related to the service sector, which is mainly centered on elitist types of leisure and ecological tourism. In this scenario, social values diminish and the global market is a key driver of change.

\section{TechnoFaith, adapted from Techno Garden}

This consumer society has decreased awareness of the importance of responsible consumption, putting their faith in 
Table 1. The main differences between scenarios in terms of the key indirect and direct drivers identified by participants. The final column describes the current conditions in the Biscay social-ecological system to compare the scenarios to current conditions.

\begin{tabular}{|c|c|c|c|c|c|}
\hline & Oppressed Biscay & Global Delicatessen & TechnoFaith & Cultivating Social Values & Present Conditions \\
\hline \multicolumn{6}{|c|}{ INDIRECT DRIVERS } \\
\hline $\begin{array}{l}\text { Global } \\
\text { demographic } \\
\text { trends }\end{array}$ & $\begin{array}{l}\text { Changes in characteristics, } \\
\text { not in quantity: } \uparrow \text { elderly } \\
\text { population, } \uparrow \text { immigrant } \\
\text { workers, } \uparrow \text { qualified youth } \\
\text { going abroad }\end{array}$ & $\begin{array}{l}\text { Migration concept changes } \\
\text { to } \uparrow \text { multiculturalism: } \\
\text { Population density remains } \\
=\text { but with } \uparrow \text { movements of } \\
\text { people }\end{array}$ & $\begin{array}{l}\text { Slight population growth: } \\
\uparrow \text { elderly population; Env. } \\
\text { refugees and armed } \\
\text { conflict entail an } \uparrow \text { in } \\
\text { immigration }\end{array}$ & $\begin{array}{l}\text { Population } \downarrow \text {. Emigration } \\
\text { from cities to rural areas } \\
\text { and to other regions }\end{array}$ & $\begin{array}{l}1,155,772 \text { inhabitants. } \\
\text { Demographic trend tends } \\
\text { toward stability }\end{array}$ \\
\hline $\begin{array}{l}\text { Changes in } \\
\text { production and } \\
\text { consumption } \\
\text { patterns }\end{array}$ & $\begin{array}{l}\uparrow \uparrow \text { delocalized } \\
\text { consumption: } \uparrow \uparrow \\
\text { importation rate. The elite } \\
\text { demand high-quality } \\
\text { healthy local food (rest } \\
\text { can't afford) }\end{array}$ & $\begin{array}{l}\text { Specialized in producing } \\
\text { local agroecological } \\
\text { products, consumed by } \\
\text { small local elite and } \\
\text { exported }\end{array}$ & $\begin{array}{l}\uparrow \text { efficiency and } \\
\text { productive systems } \\
\text { competitively. Society is } \\
\text { not worried about } \\
\text { responsible consumption }\end{array}$ & $\begin{array}{l}\text { Responsible consumption } \\
\text { and a tendency toward a } \\
\text { sustainable production and } \\
\text { toward a self-sufficiency } \\
\text { model }\end{array}$ & $\begin{array}{l}\uparrow \text { consumption, with a } \uparrow \\
\text { rate of importation. } \\
\text { Responsible consumption } \\
\text { only practiced by small } \\
\text { social groups }\end{array}$ \\
\hline $\begin{array}{l}\text { Education and } \\
\text { knowledge- } \\
\text { sharing }\end{array}$ & $\begin{array}{l}\text { Privatization of the } \\
\text { education system } \uparrow \text {, with } \\
\text { no strong education in } \\
\text { social values }\end{array}$ & $\begin{array}{l}\text { Access to knowledge } \uparrow \text {, } \\
\text { but quality } \downarrow \text {. In the first } \\
\text { years, integration conflicts } \\
\text { appear, which } \\
\text { subsequently lead to } \\
\text { multicultural education }\end{array}$ & $\begin{array}{l}\text { The population is } \uparrow \uparrow \\
\text { educated and there is an } \uparrow \\
\text { in technical degrees }\end{array}$ & $\begin{array}{l}\text { Education and knowledge } \\
\text { sharing are key. The } \\
\text { education level of Biscay's } \\
\text { population is } \uparrow \uparrow \text {, as well as } \\
\text { social participation }\end{array}$ & $\begin{array}{l}\text { The education level of the } \\
\text { citizens has } \uparrow \text { in recent } \\
\text { decades }\end{array}$ \\
\hline $\begin{array}{l}\text { Development of } \\
\text { the industrial, } \\
\text { construction, and } \\
\text { service sectors }\end{array}$ & $\begin{array}{l}\text { Economic growth is based } \\
\text { on cultural, rural, and } \\
\text { green tourism. } \\
\text { Infrastructural dev } \\
\text { maintains construction } \\
\text { sector }\end{array}$ & $\begin{array}{l}\text { Economy } \downarrow \text { as a } \\
\text { consequence of not } \\
\text { respecting nature's limits. } \\
\text { The service sector } \uparrow \\
\text { together with ecological } \\
\text { tourism }\end{array}$ & $\begin{array}{l}\text { Biscay is a knowledge and } \\
\text { technology supplier. High } \\
\text { technology sector stands } \\
\text { out }\end{array}$ & $\begin{array}{l}\text { Balance between sectors. } \\
\text { Industrial sector } \downarrow \text { weight } \\
\text { and remains a local } \\
\text { industry based on } \\
\text { renewable energies }\end{array}$ & $\begin{array}{l}\text { Industrial sector has } \\
\text { reconverted from big } \\
\text { pollutant industries to } \\
\text { medium size ones, with a } \\
\text { promotion of research } \\
\text { centers }\end{array}$ \\
\hline $\begin{array}{l}\text { Development of } \\
\text { the primary sector }\end{array}$ & $\begin{array}{l}\text { Primary sector converts } \\
\text { into a elite green tourism- } \\
\text { tertiary sector, so some } \\
\text { traditional uses are retaken }\end{array}$ & $\begin{array}{l}\text { Ecological agriculture } \uparrow \text {, } \\
\text { agrotourism } \uparrow \text { and } \\
\text { landscape quality } \uparrow \text {. Arable } \\
\text { land area } \downarrow \text { because of } \\
\text { infrastructural dev. }\end{array}$ & $\begin{array}{l}\text { Primary sector } \downarrow \text { and rural } \\
\text { areas are mainly used by } \\
\text { urban people for leisure } \\
\text { service, so importations are } \\
\uparrow \uparrow\end{array}$ & $\begin{array}{l}\text { Primary sector } \uparrow \text { and is } \\
\text { directed toward self- } \\
\text { sufficiency }\end{array}$ & $\begin{array}{l}\text { This sector's economic } \\
\text { impact is } \downarrow \text {. } \uparrow \text { dependence } \\
\text { on imported products }\end{array}$ \\
\hline $\begin{array}{l}\text { Participatory } \\
\text { policy making, } \\
\text { governance, and } \\
\text { institutional } \\
\text { coherence }\end{array}$ & $\begin{array}{l}\text { Decisions are made by a } \\
\text { few people whose } \\
\text { governance model is } \\
\text { repressive and totalitarian }\end{array}$ & $\begin{array}{l}\text { Decisions are made in a } \\
\text { global reactive way }\end{array}$ & $\begin{array}{l}\text { Multinational corporations } \\
\text { have huge decision-making } \\
\text { power. Social associations } \\
\downarrow\end{array}$ & $\begin{array}{l}\text { Government bodies are } \\
\text { simplified and decisions } \\
\text { are made in a very } \\
\text { participatory way }\end{array}$ & $\begin{array}{l}\text { Social participation is } \\
\text { medium to low and } \\
\text { participatory processes are } \\
\text { not in the center }\end{array}$ \\
\hline $\begin{array}{l}\text { Innovation, } \\
\text { science, and the } \\
\text { rapid pace of } \\
\text { technological } \\
\text { change }\end{array}$ & $\begin{array}{l}\text { Social inequality } \rightarrow \uparrow \text { the } \\
\text { rift between those with and } \\
\text { without access to } \\
\text { technology }\end{array}$ & $\begin{array}{l}\text { There is a modernization of } \\
\text { productive methods. } \\
\text { People's academic } \\
\text { knowledge } \uparrow\end{array}$ & $\begin{array}{l}\text { There is a high level of } \\
\text { innovation and dynamism } \\
\text { and rapid technological } \\
\text { advancements }\end{array}$ & $\begin{array}{l}\text { Society owns technology } \\
\text { and scientific knowledge } \\
\text { and uses it for decision } \\
\text { making }\end{array}$ & $\begin{array}{l}\text { The incorporation of new } \\
\text { technologies to industry or } \\
\text { educational system is quick }\end{array}$ \\
\hline \multicolumn{6}{|c|}{ DIRECT DRIVERS } \\
\hline $\begin{array}{l}\text { Water, air, and } \\
\text { biotic pollution; } \\
\text { soil } \\
\text { contamination; } \\
\text { Climate change. }\end{array}$ & $\begin{array}{l}\text { Invasive species expansion } \\
\text { and transgenic plant use } \\
\text { are a risk for the already } \\
\text { poor biodiversity }\end{array}$ & $\begin{array}{l}\text { Ecological agriculture } \\
\text { stimulations }+ \text { the use of } \\
\text { best available techniques } \\
\rightarrow \downarrow \text { contamination and } \\
\text { pollution }\end{array}$ & $\begin{array}{l}\text { Technological advances } \downarrow \\
\text { pollution and climate } \\
\text { change effects; generalized } \\
\text { transgenic organism use } \\
\uparrow \uparrow \text { biotic pollution }\end{array}$ & $\begin{array}{l}\text { Environmental degradation } \\
\text { and pollution } \downarrow \downarrow \text { because } \\
\text { of social and political } \\
\text { decisions in favor of } \\
\text { ecosystems }\end{array}$ & $\begin{array}{l}\text { Pollution from industries } \\
\text { has } \downarrow \text {; transport and } \\
\text { intensive farming are an } \\
\text { imp. cause of pollution }\end{array}$ \\
\hline $\begin{array}{l}\text { Ecosystem } \\
\text { degradation, river } \\
\text { alteration, } \\
\text { transformations in } \\
\text { agriculture }\end{array}$ & $\begin{array}{l}\text { All farming activities, } \\
\text { except those working for } \\
\text { elite production, are } \\
\text { abandoned }\end{array}$ & $\begin{array}{l}\text { Recovery of river basins } \\
\text { and other ecosystems; but } \\
\text { some degradation because } \\
\text { of infrastructural dev. }\end{array}$ & $\begin{array}{l}\text { Ecosystems are highly } \\
\text { modified to adapt them to } \\
\text { satisfy population's } \\
\text { demands (almost no } \\
\text { natural ecosystem exist) }\end{array}$ & $\begin{array}{l}\text { Ecosystems degradation } \\
\text { disappears as far as } \\
\text { possible }\end{array}$ & $\begin{array}{l}\text { Ecosystems are quite } \\
\text { degraded in general; } \\
\text { although some areas are } \\
\text { still well preserved or have } \\
\text { been restored }\end{array}$ \\
\hline $\begin{array}{l}\text { Intensive forest } \\
\text { management }\end{array}$ & $\begin{array}{l}\text { 1) Autochthonous forest } \\
\text { regeneration in protected } \\
\text { areas 2) Intensive high rate } \\
\text { growth plantations for } \\
\text { energetic production }\end{array}$ & $\begin{array}{l}\text { Forestry is reoriented to } \uparrow \\
\text { quality products (mainly } \\
\text { autochthonous) and } \uparrow \\
\text { sustainable management }\end{array}$ & $\begin{array}{l}\text { Some small places are } \\
\text { dedicated to forest } \\
\text { regeneration }\end{array}$ & $\begin{array}{l}\text { A sustainable forest } \\
\text { management is well } \\
\text { established. Quality and } \\
\text { autochthonous sp are } \\
\text { promoted }\end{array}$ & $\begin{array}{l}\text { Forestry is mainly based on } \\
\text { exotic short-term species } \\
\text { intensively managed }\end{array}$ \\
\hline $\begin{array}{l}\text { Land and urban } \\
\text { planning }\end{array}$ & $\begin{array}{l}\text { Heterogeneous landscape: } \\
\text { strongly protected isolated } \\
\text { natural areas; hardly } \\
\text { damaged areas, and } \\
\text { abandoned rural areas }\end{array}$ & $\begin{array}{l}\text { Tendency to cluster } \\
\text { densely and maximize } \\
\text { urbanized land use } \rightarrow \\
\text { cities do not grow, } \\
\text { although infrastructure } \\
\text { construction } \uparrow\end{array}$ & $\begin{array}{l}\text { Urban areas are built as } \\
\text { knowledge and technology } \\
\text { places, whereas rural areas } \\
\text { appear to be large peri- } \\
\text { urban parks }\end{array}$ & $\begin{array}{l}\text { There are multiple and } \\
\text { diverse land uses, forming } \\
\text { a mosaic landscape }\end{array}$ & $\begin{array}{l}\uparrow \text { in urban areas and } \\
\text { infrastructures; residential } \\
\text { urbanization } \uparrow \text { in rural areas }\end{array}$ \\
\hline
\end{tabular}


technological solutions. The population is highly educated, and there is an increase in the number of individuals holding technical degrees. The economy is based on the service sector and on intellectual products. Multinational corporations have remarkable power in governance, and there are few citizen organizations because there is little resistance to governance and because individualism is high. Ecosystems are managed to maximize profit and so are highly modified. Rural areas are mainly used for leisure for city dwellers, therefore extensive importation is necessary.

\section{Cultivating Social Values, adapted from Adapting Mosaic}

Education and knowledge sharing within society are the key to this scenario. Decision making is participatory, and society owns technology and scientific knowledge. Governance is mainly local and highly coordinated with other institutional levels. Governmental bodies are simplified, and social networks are of high importance at various scales. Social values are highly positive, i.e., participation, responsibility, and solidarity, and proactive. Consumption is highly responsible, and there is a tendency toward sustainable production and self-sufficiency. Land uses are multiple and diverse, forming a mosaic landscape of sustainable use. In this scenario, however, there is little connection with other regions and isolation becomes a negative aspect of this projection.

\section{Characterization of scenarios in terms of the provision of ecosystem services and human well-being}

Each scenario shows different developmental paths in the provision of ecosystem services and indicators of human wellbeing, which participants ascertained from the visual presentation of the scenarios. The most favorable scenario for ecosystem services and human well-being in Biscay appears to be Cultivating Social Values. In this scenario, there is a significant growth of all cultural services and in some important regulating services, such as air quality, water regulation, and erosion control. At the same time, there is an increase in most of the indicators of human well-being, however, this scenario also has some negative aspects, like the decrease in some provisioning services, i.e., fishing and forest products, and a decrease in some indicators of human wellbeing, i.e., liberty and income (Fig. 3). This decrease in income and liberty occurs because a barter system largely replaces money and because the concept of liberty in this scenario is closely related to responsible consumption and lifestyle; thus, the accepted definition of liberty changes.

On the other hand, the least favorable scenario is Oppressed Biscay with a general decrease in ecosystem provisioning services and in indicators of human well-being, except for increased security, which is not linked to other positive social indicators. TechnoFaith and Global Delicatessen scenarios present growth of some ecosystem services and indicators of human well-being, although there are many negative aspects, such as the decrease in provisioning services, good social relations, and liberty (Fig. 3).
The evolution of ecosystem services and human well-being under each of the four scenarios depends on the path of development, i.e., global-regional, and on the type of management, i.e., reactive-proactive. The key aspects of the Cultivating Social Values scenario are high participation and responsibility, balanced economic sectors, local green industry, growth of the primary sector, education in values, and landscape multifunctionality. Participants argue that this scenario would be possible only if the population were smaller. On the other hand, the key aspects of the Oppressed Biscay scenario are as follows: growth of the tertiary sector, high importation, high privatization of the education system, conservation of nature systems only in protected areas, and high rates of immigration and emigration (Fig. 4).

\section{Target scenario description and management strategies for Biscay social-ecological system}

The use of a visual presentation of the described EEMBiscay scenarios allowed the extraction of the most positive elements from the different scenarios and allowed participants to focus on the Cultivating Social Values scenario as the most desirable choice. The target scenario chosen by general consensus was named "Biscay from the local to the global scale and vice versa", in which: (1) proactive work is carried out from the local to the global scale and vice versa; (2) education, local participation, and knowledge societies are key; (3) local productivity is reinforced, and the quality and variety of forest and agricultural products are improved; and (4) society owns technology and scientific knowledge and uses them to protect ecosystem functionality. In summary, the selected and described target scenario takes the Cultivating Social Values scenario and adds more multiculturalism and interregional connections. Positive aspects also taken from other scenarios included local organic productivity and natural forest regeneration, specially highlighted in the Global Delicatessen scenario, and development of knowledge and technology to support sustainability, which was key in the TechnoFaith scenario.

Management strategies needed to achieve the target scenario were proposed by participants. Table 2 shows the strategic objectives and main management actions proposed by participants regarding the ecosystem services and human wellbeing variables. Participants highlighted the necessity for coherent and coordinated policies. Education in social values, landscape planning, and forest management were also considered key elements.

\section{DISCUSSION}

\section{Biscay scenarios: forest management relevance and population density constraints}

Pollution and land management were considered the most important direct drivers of change in the area. In relation to pollution, air quality was considered the most important ecosystem service, most likely because Biscay is highly 
Fig. 3. Provision of ecosystem services and indicators of human well-being under each scenario, compared to the current conditions ( substantial increase $=2$; increase $=1$; constant or increases in same aspects and decreases in other aspects $=0$; decrease $=1$; large decrease $=2$ ). Name codes: Sci \& Know = Science \& Knowledge; Rec Act = Recreational activities; Env Educ = Environmental education; Trad Know = Traditional knowledge; Aest \& Spir = Aesthetic and spiritual values; Local Id = Local identity; Agricul = Agriculture; Wat Sup = Water supply; For Pro = Forest products; Geo Res = Geological resources; $\mathrm{C}$ storage $=$ Carbon storage; Air qual $=$ Air quality; Clim reg = Climate regulation; Wat reg = Water regulation; Eros \& Soil = Erosion control \& soil fertility; Distur mit = disturbance mitigation; Biodiv = Biodiversity; Lib E \& Act = Liberty of election and action; $\mathrm{G}$ social rel = Good social relations; Fossil $\mathrm{f}$ cons red = Fossil fuel consumption reduction; Employm = Employment. In some cases, as in the case of security in the Oppressed Biscay scenario, increases are not linked to social positive aspects, and decreases are not always negative (e.g., in the Cultivating Social Values scenario, liberty is closely related to responsibility and consumption is limited, so the accepted definition of liberty is transformed).

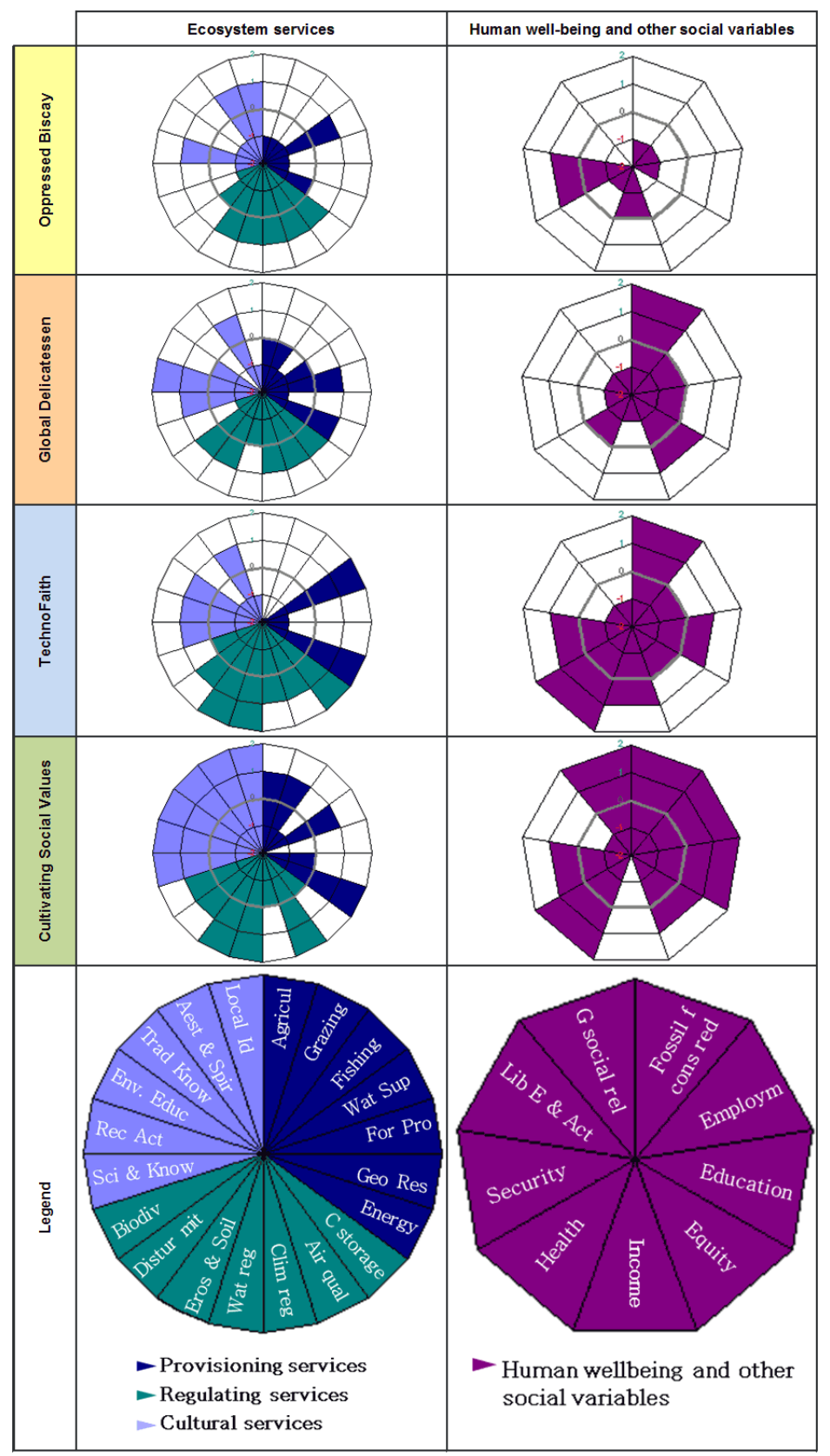


Table 2. Strategic objectives and main management actions proposed by participants for the Biscay social ecological system regarding the ecosystem services and human well-being variables. Common aspects are shown separately. ES = ecosystem services.

\begin{tabular}{|c|c|c|}
\hline $\begin{array}{l}\text { ES and human well- } \\
\text { being variables }\end{array}$ & Strategic objectives & Main management actions proposed \\
\hline Provisioning services & $\begin{array}{l}\text { Reinforce local sustainable } \\
\text { productivity; improve the quality } \\
\text { and variety of forest and } \\
\text { agricultural products }\end{array}$ & $\begin{array}{l}\text { - New financial mechanism will be created } \\
\text { - Local and sustainable production, as well as direct and responsible consumption will be } \\
\text { promoted } \\
\text { - Incentives for eco-innovation and for the promotion of sustainable construction are needed } \\
\text { - The use of renewable energy will be promoted } \\
\text { - A strategic landscape management plan is needed to tackle this sustainability objective }\end{array}$ \\
\hline Regulating services & $\begin{array}{l}\text { Conserve Biscay's ecosystems and } \\
\text { their functionality, and recover key } \\
\text { autochthonous ecosystems }\end{array}$ & $\begin{array}{l}\text { - Changes in forest management and landscape planning are needed in an integrative and } \\
\text { proactive way } \\
\text { - More coordination between policy makers and researchers is needed. } \\
\text { - Strategic and well-balanced planning is needed: } \\
\text { - Taking into account ecosystems multifunctionality } \\
\text { - Recognizing Biscay's rich biodiversity and geodiversity heritage } \\
\text { - Including a well-balanced planning of the urban social-ecological systems }\end{array}$ \\
\hline Cultural services & $\begin{array}{l}\text { Society owns technology and } \\
\text { scientific knowledge and uses it to } \\
\text { favor ecosystems functionality }\end{array}$ & $\begin{array}{l}\text { - Promotion of environmental education from early stages is a key aspect } \\
\text { - Scientific and local knowledge shall be spread to society through educational campaigns } \\
\text { - A strong link between natural heritage and cultural heritage is needed }\end{array}$ \\
\hline $\begin{array}{l}\text { Human well-being and } \\
\text { other social variables }\end{array}$ & $\begin{array}{l}\text { Education, local participation, and } \\
\text { knowledge society are key }\end{array}$ & $\begin{array}{l}\text { - An education more based in social and ethics values will be promoted } \\
\text { - Change in consumption habits and limits to squander are needed } \\
\text { - More planning is needed to guarantee a better connection between education and training to } \\
\text { local employment needs. } \\
\text { - Leisure and aspects related to well-being will be dematerialized } \\
\text { - The possible impact on health will be assessed before taking any decision } \\
\text { - A social urbanism is proposed, in which different urban planning is performed and diverse } \\
\text { land uses are mixed }\end{array}$ \\
\hline Common aspects & $\begin{array}{l}\text { Proactive work is performed from } \\
\text { local to global and vice versa }\end{array}$ & $\begin{array}{l}\text { - Coherence between policy and actions is needed: governments at different scales have an } \\
\text { important role to play } \\
\text { - Reinforce public awareness on the importance of acting proactively for a more sustainable } \\
\text { and responsible consumption } \\
\text { - A change in consumption habits is needed: consume less and of better quality. To achieve } \\
\text { this objective, the importance of education is highlighted. } \\
\text { - Social and associative participation appear to be key pieces } \\
\text { - Internalization of environmental cost } \\
\text { - Promote natures' nonmaterial goods } \\
\text { - Biscay's landscape diversification }\end{array}$ \\
\hline
\end{tabular}

industrialized and has a heavy industrial past. Land management, particularly woodlands management, was also an important driver of ecosystem services. In fact, the forest and its associated services significantly influenced the development of scenarios in Biscay. Therefore, future directions in forest management may significantly influence the Biscay landscape. Local and regional land-use management plans are crucial in strategic planning to create sustainable landscapes. A key point in the target scenario "Biscay from the local to the global scale and vice versa" is landscape multifunctionality, which includes increased agriculture for self-provision and a change in the production model used by the primary sector. In this scenario, sustainable forest management enhances biodiversity, alleviates floods, and controls erosion and soil fertility. It also creates opportunities for recreation and other cultural services. The relevance of tackling landscape multifunctionality with sustainability objectives has also been detected in other recent studies carried out under the Ecosystem Services Framework (Haines-Young et al. 2011, Palomo et al. 2011). Thus, multifunctional forest management seems to be an appropriate solution for the Biscay social-ecological system, which was 
Fig. 4. Summary of the evolution of ecosystem services and human well-being under each of the four scenarios. The vertical axis indicates two paths of global development: one in which the world becomes increasingly globalized and the other in which it becomes increasingly regionalized; and the horizontal axis indicates different approaches to ecosystem management, one in which actions are reactive and the other in which ecosystem management is proactive. Key aspects of each scenario are highlighted.

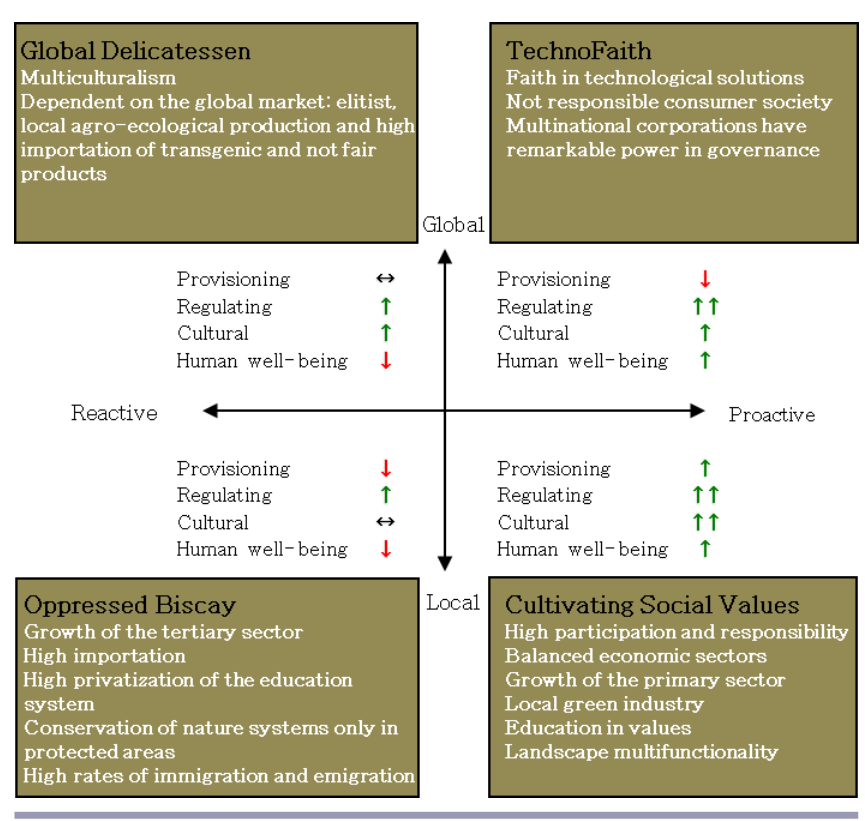

also highlighted in the backcasting exercise. However, it is not easy to manage forests in such a way that user groups, sustainability practitioners, and forestry institutions are all in agreement. To reach a consensus, it is necessary to negotiate a set of common objectives and shared responsibilities (Carvalho-Ribeiro et al. 2010). Backcasting results also show that strategic landscape planning and management are needed, which would include changes in forest management in an integrative and proactive way. This participatory scenario description process, together with its associated management proposal and social learning, has been shown to be relevant for local policy. In fact, it may lay the foundations for sustainable land-use planning in Biscay.

Additionally, provisioning services, such as energy supply and other regulating services, are considered very important. However, currently it is recognized that interventions occur mainly at high levels rather than through local influence. Likewise, cultural services, especially environmental education, are considered important and it is believed that there is a high potential for successful intervention in these areas. In this subglobal assessment scenario exercise the importance of biodiversity, water regulation, and water supply ecosystem services are recognized, and therefore they are addressed explicitly as in in many other subglobal assessments (Lebel et al. 2005). The major indirect drivers of change are similar to those identified in other areas (Nelson et al. 2005, HainesYoung et al. 2011) because they are global: demographic trends, production and consumption patterns, education, knowledge and science, development of economic sectors, and governance.

During this scenario description exercise, participants were surprised to find out that Biscay's future is greatly challenged as it addresses sustainability because of its large population density. In this sense, it is remarkable that fishing services decrease under each of the four scenarios. Defining the target scenario in which there is a tendency toward sustainable production and self-provisioning, participants realized that Biscay does not provide sufficient food for its population, and therefore, for this scenario to be possible, the population would have to be smaller than it currently is. Becoming self-sufficient in the provision of food and other ecosystem services, although desired, was seen as very challenging considering the current context of high importation rates and significant use of overseas ecosystem services (EEMBiscay 2010). These overconsumption and high-density population problems are common in different industrialized regions (Haines-Young et al. 2011) and merit increased attention. Regarding the opportunities of society to adapt to these significant dangers, participants highlighted the necessity for coherent, coordinated, and exemplary policies to address such a challenge. Education in social values, landscape planning, and forest management were also considered key elements.

The target scenario proposes a real change in social values. This scenario involves a transformation of the concept and practice of liberty. The new concept of liberty is related to the necessity of responsibility and consumption control. Participants highlighted society's change and adaption capabilities and stated that policymakers should promote responsible consumption and lifestyle changes. Among the most important key drivers of this scenario are the development of a local green industry and a new type of valuesbased education. These ideas for more sustainable city life, including more local and organic food, a greener environment, and a reorientation of values, appear to be a common trend in the European Union (Carlsson-Kanyama et al. 2008).

\section{Linking subglobal scenarios to Millennium Ecosystem Assessment (MA) global scenarios: the scale issue}

The exercise, based on the Millennium Ecosystem Assessment scenarios (MA 2005b), revealed key drivers and trade-offs in ecosystem services. At subglobal scales, scenarios proposed by the Millennium Ecosystem Assessment are a powerful vehicle for communication and the engagement of decision makers (Bohensky et al. 2006). Downscaling MA global 
scenarios was a successful way to explore the effects of external global actors and market forces on Biscay's future.

An important trade-off exists between maintaining relevance to stakeholders at different scales and maintaining consistency across scales to allow for comparison of scenarios (Biggs et al. 2007, Kok et al. 2007). Most subglobal assessment scenarios developed during the MA process described their scenarios based mainly on the relevant factors at their specific scale, and therefore a problem encountered by all assessments was the relatively poor link between the various subglobal scales (Lebel et al. 2005). In the Biscay subglobal assessment, however, we considered maintaining a scientifically credible global context to be of primary interest, particularly considering that we depend on ecosystem services that are not located in Biscay, as occurs in other industrialized regions (Weighell 2011). The MA scenarios were developed to provide a comprehensive overview of the possible changes in drivers of change to ecosystems and their services (MA 2005a, $b$, Sala et al. 2006). These MA scenarios were developed using both qualitative, i.e., storytelling, and quantitative, i.e., modeling, approaches that mutually support each other. The modeling approach uses several global models that were coupled for this assessment, i.e., for a selected number of main variables the output of one model is used as input of the next model (Alcamo et al. 2006). As well, the MA effort stimulated renewed interest in the potential for multiscale scenario development because it potentially has much greater local policy relevance than most previous global environmental assessments (Lebel et al. 2005). For this reason, we used a downscaling methodology that allowed stakeholders' creativity and local variability, while maintaining consistency and coherency across scales. EEMBiscay scenarios were a mixture of high-level developments and local specifics. The outcome scenarios, therefore, have local management relevance, and at the same time, they can be compared to other assessments. In this way, the understanding of local processes and their interrelation to global processes is increased, enabling the improvement of landscape-level management by exploring collaboratively possible response options.

Contrary to the SAfMA, in which scenarios were constructed independently from the MA four global storylines and linked afterward (Biggs et al. 2004, Kok et al. 2007), the EEMBiscay scenarios used MA global scenarios as a starting point and then adapted them to address local and specific uncertainties. The Portugal MA scenarios adopted a similar approach at a national scale, but in this case, the scenario development process was done without a stakeholder participatory process (Pereira et al. 2006, 2009). All these different multiscale scenario approaches offer the possibility to better study crossscale linkages (Zurek and Henrichs 2007). The Biscay subglobal assessment also gives some new insight on how the MA global scenarios' work can be used at the local scale to diminish time and resource consumption in the creation of local scenarios but still maintain a scientifically credible global context. Instead of including specific mathematical models for the Biscay scenarios, we used global MA scenarios that included mathematical models together with qualitative methodologies (Alcamo et al. 2006). Therefore, in this local, participatory scenario-planning process, we could focus more on society's perceptions and reactions to the described plausible futures, and consequently, work on constructing alternatives and response options. Providing and constructing greater resilience is a great advantage with this kind of scenario-planning process, which makes this type of process relevant to policy making.

Because global drivers play a relevant role in the current context, it was not difficult for participants to think locally but still take into account the global context. However, the downscaling exercise was influenced by the current global socioeconomic differences. Thus, some scenario developments expected to occur globally, such as hunger alleviation or population increase, during the first decades of the Global Orchestration scenario had a different development path in EEMBiscay scenarios because of the characteristics of Biscay's economically developed postindustrialized region. Downscaling the Order From Strength scenario, participants were resistant to thinking that the future could be that way, but they were still able to imagine the possibility and think of ways to ensure it does not occur. On the contrary, the Adapting Mosaic scenario, which a priori could be the closest to the desired scenario, was the one that in the downscaling process showed more clearly how challenging it was for Biscay to achieve a sustainable future. Becoming self-sufficient in the provision of food and other ecosystem services would be extremely challenging, therefore, the Adapting Mosaic scenario was more difficult to translate to Biscay than was expected. After all, it is the scenario that requires more transformations in today's society, including changes in population density and lifestyle. In this downscaling process, all participants reflected upon the challenges and opportunities to construct a fairer and more sustainable future, and at the same time, they could see what pathways they would and would not like for the future of their region and the world. The learning from this first exploratory workshop were key to the second workshop in which policy responses were explored. During this scenario-planning process, the adaptation potential of the area and its inhabitants was recognized. Even if the changes needed to lead innovative and sustainable land management are challenging, social resilience provides an opportunity for the required social-political transformations.

\section{Lessons learned from the applied methodology}

Understanding how human well-being increases in relation to good ecosystem conditions is critical for guiding the future management of ecosystem services. Policies for the management of ecosystem services must be based on a broader understanding of value and drivers of human well-being 
(Nicholson et al. 2009). Local government agencies and land managers can use scenarios to develop policy interventions that consider local human capacities, willingness, and environmental factors (Van Berkel et al. 2011). Applying participatory methodologies in the scenario-planning process enables stakeholders to understand existing trade-offs among ecosystem services, and as a result, build an ecosystem services-oriented management strategy (Rodríguez et al. 2006, Bennett et al. 2009). Engaging local stakeholders, and in particular key decision makers, in the process is an important strength of most subglobal assessments (Lebel et al. 2005).

The EEMBiscay assessment worked hard to ensure stakeholder participation from the very beginning (Booth et al. 2012). Thus, by the time the EEMBiscay scenariosplanning process started, the stakeholder-engagement process already existed. This near and continuous contact ensured a widespread buy-in of the scenario exercises from a range of key stakeholders. A good working environment was achieved, which enabled the inclusion of group variability and facilitated the search for consensus. This broad participation allowed for the making use of local and specialized knowledge, which has been identified as one of the main reasons for conducting participatory scenario exercises (Patel et al. 2007).

For the applied methodology to be successful, workshops must be prepared thoroughly. Biscay's scenarios working team consisted of researchers, representatives of local administrations and NGOs, and facilitators specialized in scenario workshops. Additionally, two members of the Spanish national assessment, experienced in scenario methodologies, were involved. Before the workshops, questionnaires were prepared, tested, and administered; many key stakeholders were personally contacted; the objectives of the workshops were clearly defined and communicated; the agenda of the workshops was designed; and the methodologies were established in a well-coordinated manner. Administering a survey before the workshops saved time. This included a ranking of potential for successful interventions, which measured the intervention capacity from the region and provided a starting point to explore policy relevance and suggest management strategies. Although stakeholders showed a lot of ownership in the process and the resulting scenarios, during the workshop, we failed to ask participants to choose a name for their scenario. To address this lack, after the workshops, we contacted participants for the naming of the scenarios. We would have saved time and reached a larger consensus on Biscay scenario names if we had asked them to work on it during the workshops. This illustrates the importance of having every detail organized from the outset to maximize the efficiency of the workshops.

Organizing back-to-back workshops saved time, allowed participants to easily retain the learning and experiences from the previous workshop, and made it easier to get the same stakeholders to attend. Having participants thinking about different possible scenarios, in which some had to face undesired pathways, and out of which arose thoughts on what could be done to avoid them, while others had a theoretically ideal scenario that, however, showed existing trade-offs regarding land use and population constraints, enabled greater creativity the following day in the proposal of policy responses. During the second day workshop, participants were constantly mixed in a random way, which improved the synergies and the quality of the contributions.

Several authors have defended the usefulness of combining exploratory scenario development and backcasting analysis for managing social-ecological systems (Robinson 2003, Kok et al. 2011, Palomo et al. 2011). However, the backcasting approach has not been used with many scenario processes. Biscay's participatory scenario-planning process applied this combination, and additionally, used a World Café methodology in the backcasting analysis, which gives some new insights on the use of feasible, practical, and useful methodology for scenario planning in social-ecological systems. In other subglobal assessment scenario exercises, stakeholders were preoccupied with tangible outputs (Lebel et al. 2005), but in this subglobal assessment, combining exploratory scenarios with backcasting exercises enabled participants to better understand the utility of the scenarios. Moreover, the mix of exploratory scenarios and normative backcasting enabled participants to reduce the gap in some confronted postures, e.g. stakeholders were more able to understand other stakeholders' views regarding forest management after taking part in this participatory process. Therefore, group cohesion was built and creativity arose. This participatory, scenario-building process facilitated social learning, which is considered the most appropriate way to assess the success of such a study (Hulme and Dessai 2008). A difficult aspect of this mix of methodologies was making participants understand the connections of the overall process while they were living it. At the end of the workshops, participants could see the connections and stated that the results of the backcasting process would have not been as fruitful without the previous day's exploratory process, during which they reflected on the future along with a wide range of other stakeholders.

Probably the most important thing that stakeholders learned during the scenario-planning process was to see different perspectives and begin to understand different points of view, e.g., public administration personnel explained to NGO members the different aspects regarding the pace and proceedings of the administration while the NGO members expounded on relevant aspects that should be considered in ecosystem-based management. The desired future outcome focused on the common well-being, and therefore, common interests gained relevance. This broader view allowed participants to work on achieving shared solutions and to 
propose feasible, coherent, and commonly desired response options. Thus, this scenario-planning process, based on consensus building, enabled decision making that would be supported by society. This reinforcement was much appreciated by the policy makers involved in the EEMBiscay assessment, who make use of the results of the process to influence regional administration decision making. Therefore, this planning process is relevant for ecosystem management policies in the Basque Country.

\section{Exploring the policy relevance}

The Millennium Ecosystem Assessment in Biscay subglobal assessment has worked to strengthen the link to policy making since it started in 2008 (Madariaga et al. 2010). This is because it had an innovative structure from the beginning. The EEMBiscay core team is comprised of representatives from the university, the regional administration, and a local NGO. This interconnectedness enables results to be easily spread to people in society and used for management purposes. In fact, the regional government involvement guarantees that the results of the assessment will be implemented in ecosystem management policies. The stakeholder involvement process enriches every phase of the assessment.

The management proposals derived from this scenarioplanning process highlight the necessity of coherent and coordinated policies. Public administration technicians and policymakers involved in the assessment are working to involve more and more personnel from different areas of the regional administration, as well as to have an impact on strategic policy planning. As a result, the 'Biscay 21 program," renewed on July 2012, considers the EEMBiscay assessment a high priority for the County Council of Biscay and includes specific actions for its promotion (BFA/DFB 2012).

The exploration of the policy's relevance shows that it is important to be conscious of the different rates of potential for successful intervention at the subnational scale that different policies can have. Our results show that a positive impact is more likely to be had in policies with a high potential of successful intervention, e.g., environmental education rather than energy supply, where interventions occur mainly at higher levels. With this in mind, it is important to explore how the link to policy making can be strengthened. Scale remains a key aspect and interconnections among different scales should be further studied. Another aspect to be considered is that not all the proposals have the same level of consensus among stakeholders. For example, landscape planning and forest management were identified as key aspects for Biscay' future, but a wider consensus is required. Much work is still needed to analyze the existing trade-offs and to promote positive synergies in landscape planning and forest management.

\section{CONCLUSION}

This local participatory scenario process and tool for landscape planning created a widespread buy-in from a range of key stakeholders in the EEMBiscay assessment. The scrupulously selected combination of participatory methodologies represents a novel approach that facilitates consensus building and allows for saving both time and resources. The successfully applied specific methodological novel elements include: organizing back-to-back workshops, creating coherent scenarios across scales, using visual elements to present exploratory scenarios, and combining exploratory scenarios with normative backcasting using a World Café methodology. From this scenario-planning process we learned about the importance of taking into account different perspectives when dealing with ecosystem management and also became aware of the crucial importance of involving policymakers and administration technicians in the process to gain policy impact. The outcome scenarios and management proposals are relevant for decision making and planning processes on a local scale, and at the same time, they are comparable to other assessment scenarios. This local, participatory, scenario-planning process is already having a policy impact thanks to the involvement of public administration technicians and policymakers on the recently renewed strategic policy planning for sustainability of the Biscay County. This assessment is considered a high priority, and therefore, for the next steps of the assessment, detailed guidelines for ecosystem management policies are planned. Thus, the results of this scenario-planning process are going to be used as a basis for ecosystem management policies.

Responses to this article can be read online at: http://www.ecologyandsociety.org/issues/responses. $\mathrm{php} / 5619$

\section{Acknowledgments:}

The authors gratefully acknowledge the Environment Department of the County Council of Biscay for funding the Millennium Ecosystem Assessment in Biscay project and for providing data-collection facilities, They would like to especially thank X. Arana. The authors also gratefully acknowledge the Department of Education, University and Research of the Basque Government for the doctoral grant received by Izaskun Casado-Arzuaga (BFI09.231). We thank I. Palomo for his helpful comments on the workshops design. We also thank Prospektiker, UNESCO Etxea, and the SocialEcological Systems Laboratory of the UAM for their help in the facilitation of the workshops. Special thanks go out to local stakeholders for taking time to respond to the questionnaire and participating in the workshops. Finally, we would like to thank the two anonymous reviewers for their helpful comments. 


\section{LITERATURE CITED}

Alcamo, J. A., D. P. van Vuuren, and W. Cramer. 2006. Changes in provisioning and regulating ecosystem goods and services and their drivers across the scenarios. Pages 297-374 in Millennium Ecosystem Assessment. Ecosystems and human well-being: findings of the Scenarios Working Group. Island, Washington, D.C., USA. [online] URL: http://www. unep.org/maweb/documents/document.333.aspx.pdf

Amezaga, I., and M. Onaindia. 1997. The effect of evergreen and deciduous coniferous plantations on the field layer and seed bank of native woodlands. Ecography 20:308-318. http:// dx.doi.org/10.1111/j.1600-0587.1997.tb00375.x

Andersen, I.-E., and B. Jaeger. 1999. Scenario workshops and consensus conferences: towards more democratic decisionmaking. Science and Public Policy 26(5):331-340. http://dx. doi.org/10.3152/147154399781782301

Basque Government. 2005. Forest inventory of the CAE 2005 in 1:10000 scale. [online] URL: http://www.geo.euskadi.net/ s69-geodir/en/contenidos/informacion/recursoagricultura2009/ en 20/agricultura.html

Bennett, E. M., G. D. Peterson, and L. J. Gordon. 2009. Understanding relationships among multiple ecosystem services. Ecology Letters 12:1394-1404. http://dx.doi. org/10.1111/j.1461-0248.2009.01387.x

Berkes, F., and I. J. Davidson-Hunt. 2006. Biodiversity, traditional management systems, and cultural landscapes: examples from the boreal forest of Canada. International Social Science Journal 58:35-47. http://dx.doi.org/10.1111/ j.1468-2451.2006.00605.x

Biggs, R., E. Bohensky, P. V. Desanker, C. Fabricius. T. Lynam, A. A. Misslehorn, C. Musvoto, M. Mutale, B. Reyers, R. J. Scholes, S. Shikongo, and A. S. van Jaarsveld. 2004. Nature supporting people: the Southern African millennium ecosystem assessment. Council for Scientific and Industrial Research, Pretoria, South Africa. [online] URL: http://www. unep.org/maweb/documents sga/safma integrated report.pdf

Biggs, R., C. Raudsepp-Hearne, C. Atkinson-Palombo, E. Bohensky, E. Boyd, G. Cundill, H. Fox, S. Ingram, K. Kok, S. Spehat, M. Tengö, D. Timmer, and M.Zurek. 2007. Linking futures across scales: a dialogue on multiscale scenarios. Ecology and Society 12(1): 17. [online] URL: http://www. ecologyandsociety.org/vol12/iss 1/art17/

Bohensky, E. L., B. Reyers, and A. S. van Jaarsveld. 2006. Future ecosystem services in a Southern African river basin: a scenario planning approach to uncertainty. Conservation Biology 20:1051-1061. http://dx.doi.org/10.1111/ j.1523-1739.2006.00475.x

Booth, H., L. Simpson, M. Ling, O. Mohammed, C. Brown, K. Garcia, and M. Walpole. 2012. Lessons learned from carrying out ecosystem assessments: experiences from members of the Sub-Global Assessment Network. United Nations Environment Programme/World Conservation Monitoring Centre, Cambridge, UK. [online] URL: http:// www.ecosystemassessments.net/news/96-new-lessons-learnedreport.html

Brown, J., and D. Isaacs. 2005. The World Café: shaping our futures through conversations that matter. Berrett-Koehler, San Francisco, California, USA.

Brunckhorst, D., P. Coop, and I. Reve. 2006. 'Eco-civic' optimisation: a nested framework for planning and managing landscapes. Landscape and Urban Planning 75:265-281. http://dx.doi.org/10.1016/j.landurbplan.2005.04.001

Butler, C. D., R. Chambers, K. Chopra, P. Dasgupta, A. Duraiappah, P. Kumar, A. J. McMichael, and N. Wen-Yuan. 2003. Ecosystems and human well-being. Pages 71-84 in Millennium Ecosystem Assessment. Ecosystems and human well-being: a framework for assessment. Island, Washington, D.C., USA. [online] URL: http://www.unep.org/maweb/ documents/document.301.aspx.pdf

Carlsson-Kanyama, A., K. H. Dreborg, H. C. Moll, and D. Padovan. 2008. Participative backcasting: a tool for involving stakeholders in local sustainability planning. Futures 40 (1):34-46. http://dx.doi.org/10.1016/j.futures.2007.06.001

Carpenter, S. R., and C. Folke. 2006. Ecology for transformation. Trends in Ecology and Evolution 21 (6):309-315. http://dx.doi.org/10.1016/j.tree.2006.02.007

Carvalho-Ribeiro, S. M., A. Lovett, and T. O'Riordan. 2010. Multifunctional forest management in northern Portugal: moving from scenarios to governance for sustainable development. Land use policy 27(4):1111-1122. http://dx.doi. org/10.1016/j.landusepol.2010.02.008

Casado-Arzuaga, I., I. Madariaga, and M. Onaindia. 2013. Perception, demand and user contribution to ecosystem services in the Bilbao Metropolitan Greenbelt. Journal of Environmental Management 129:33-43. http://dx.doi. org/10.1016/j.jenvman.2013.05.059

Cork, S., G. Peterson, G. Petschel-Held, J. Alcamo, J. Alder, E. M. Bennett, E. R. Carr, D. Deane, G. C. Nelson, T. Ribeiro, C. Butler, E. M. Mendiondo, W. Olouch-Kosura, and M. Zurek. 2005. Four scenarios. Pages 223-294 in Millennium Ecosystem Assessment (MA). Ecosystems and human wellbeing: findings of the Scenarios Working Group. Island, Washington, D.C., USA. [online] URL: http://www.maweb. org/en/Scenarios.aspx

County Council of Biscay (BFA/DFB). 2012. Approval of the updated Biscay 21 program: a County Council of Biscay strategy for sustainability 2011-2016. Official Bulletin of Biscay (BOB) 130:July 6, 2012. [online] URL: http://www. 
euskadi.net/contenidos/informacion/ura gardena gr concesiones/ es def/adjuntos/BOB130.pdf

Eustat: Basque Statistics Office. 2011. Gross added value by province and sector (base 2005) (\% ). 2008. Eustat, San Sebastián, Spain. [online] URL: http://en.eustat.es/ci ci/ elementos/ele0000500/ti_Gross added_value by province and sector base 2005 2008/tb10000543 i.html\#axzz1oXSu2tkC

Eustat: Basque Statistics Office. 2013. Population of the Basque Country classified by year of birth, according to historic territory and sex on 11/1/2011. Eustat, San Sebastián, Spain. [online] URL: http://en.eustat.es/elementos/ele0008400/ ti_Population_of_the_Basque_Country_classified_by_year_of birth according to Historic Territory an sex on XI12011/ $\underline{\text { tbl0008457 i.html\#axzz2ZrEgnzHJ }}$

Groome, H. J. 1990. Historia de la política forestal en el estado español. Agencia de Medio Ambiente, Madrid, Spain.

Gunderson, L. H., C. S. Holling, and S. S. Light, editors. 1995. Barriers and bridges to the renewal of ecosystems and institutions. Columbia University Press, New York, New York, USA.

Haines-Young, R., J. Paterson, M. Potschin, A. Wilson, and G. Kass. 2011. The UK NEA scenarios: development of storylines and analysis of outcomes. Pages 1195-1264 in The UK National Ecosystem Assessment Technical Report. UK National Ecosystem Assessment, United Nations Environment Programme/World Conservation Monitoring Centre, Cambridge, UK. [online] URL: http://www.nottingham.ac.uk/cem/pdf/ NEA_Ch25_Scenarios_Haines-Young_et\%20al\%20_2011.pdf

Heemskerk, M. 2003. Scenarios in anthropology: reflections on possible futures of the Suriname Maroons. Futures 35:931-949. http://dx.doi.org/10.1016/S0016-3287(03)00050-8

Henrich, T., M. Zurek, B. Eickhout, K. Kok, C. RaudseppHearne, T. Ribeiro, D. van Vuuren, and A. Volkery. 2010. Scenario development and analysis for forward-looking ecosystem assessments. Pages 151-220 in N. Ash, H. Blanco, C. Brown, K. Garcia, T. Henrichs, N. Lucas, C. RaudseppHearne, R. D. Simpson, R. Scholes, T. Tomich, B. Vira, and M. Zurek, editors. Ecosystems and human well-being: a manual for assessment practitioners. Island, Washington, D. C., USA.

Hjorts $\varnothing$, C. N. 2004. Enhancing public participation in natural resource management using Soft OR - an application of strategic option development and analysis in tactical forest planning. European Journal of Operational Research 152:667-683. http://dx.doi.org/10.1016/S0377-2217(03)00065-1

Hulme, M., and S. Dessai. 2008. Predicting, deciding, learning: can one evaluate the 'success' of national climate scenarios? Environmental Research Letters 3:045013. http:// dx.doi.org/10.1088/1748-9326/3/4/045013
Huss, W. R. 1988. A move toward scenario analysis. International Journal of Forecasting 4:377-388. http://dx.doi. org/10.1016/0169-2070(88)90105-7

Jessel, B., and J. Jacobs. 2005. Land use scenario development and stakeholder involvement as tools for watershed management within the Havel river basin. Limnologica 35:220-233. http://dx.doi.org/10.1016/j.limno.2005.06.006

Kok, K., R. Biggs, and M. Zurek. 2007. Methods for developing multiscale participatory scenarios: insights from southern Africa and Europe. Ecology and Society 12(1): 8. [online] URL: http://www.ecologyandsociety.org/vol12/iss1/ art8/

Kok, K., M. Patel, D. S. Rothman, and G. Quaranta. $2006 a$. Multi-scale narratives from an IA perspective. Part II. Participatory local scenario development. Futures 38:285-311. http://dx.doi.org/10.1016/j.futures.2005.07.006

Kok, K., D. S. Rothman, and M. Patel. 2006b. Multi-scale narratives from an IA perspective. Part I. European and Mediterranean scenario development. Futures 38:261-284. http://dx.doi.org/10.1016/j.futures.2005.07.001

Kok, K., M. van Vliet, I. Bärlund, A. Dubel, and J. Sendzimir. 2011. Combining participative backcasting and exploratory scenario development: experiences from the SCENES project. Technological Forecasting and Social Change 78:835-851. http://dx.doi.org/10.1016/j.techfore.2011.01.004

Lebel, L., P. Thongbai, K. Kok, J. B. R. Agard, E. Bennett, R. Biggs, M. Ferreira, C. Filer, Y. Gokhale, W. Mala, C. Rumsey, S. J. Velarde, M. Zurek, H. Blanco, T. Lynam, and Y. Tianxiang. 2005. Subglobal scenarios. Pages 227-258 in D. Capistrano, C. K. Samper, M. J.Lee, and C. Raudsepp-Hearne, editors. Ecosystems and human well-being volume 4: multiscale assessments. Findings of the Sub-global Assessments Working Group of the Millennium Ecosystem Assessment. Island, Washington, D.C., USA.

Leslie, A. D., M. Mencuccini, and M. Perks. 2012. The potential for eucalyptus as a wood fuel in the UK. Applied Energy 89:176-182. http://dx.doi.org/10.1016/j.apenergy.2011.07.037

Lynam T., W. de Jong, D. Sheil, T. Kusumanto, and K. Evans. 2007. A review of tools for incorporating community knowledge, preferences, and values into decision making in natural resources management. Ecology and Society 12(1): 5. [online] URL: http://www.ecologyandsociety.org/vol12/iss1/ $\underline{\operatorname{art5/}}$

Madariaga, I., X. Arana, I. Casado-Arzuaga, and I. PalaciosAgúndez. 2010. Evaluación de los ecosistemas del milenio en Bizkaia: conocimiento compartido entre la comunidad científica, política, gestora y la sociedad civil. Pages 47-52 in N. Viota and M. Maraña editors. Servicios de los ecosistemas y bienestar humano. La contribuciún de la evaluaciún de los 
ecosistemas del milenio. UNESCO Etxea, Bilbao, Spain. [online] URL: http://www.unescoetxea.org/dokumentuak/ Ecosistemas bienestar.pdf

Madariaga I., X. Arana, I. Casado-Arzuaga, and I. PalaciosAgúndez. 2011. Servicios de los ecosistemas del paisaje cultural de Bizkaia. Perspectiva histórica de la actividad forestal y minera. Revista Forum de Sostenibilidad 4:33-46. [online] URL: http://www.ehu.es/cdsea/web/revista/numero 4/ $\underline{\text { Servicios_ecosistemas_paisaje_cultural_Bizkaia.pdf }}$

Merino, A., A. Fernández-Lúpez, F. Solla-Gullón, and J. M. Edeso. 2004. Soil changes and tree growth in intensively managed Pinus radiata in northern Spain. Forest Ecology and Management 196:393-404. http://dx.doi.org/10.1016/j.

foreco.2004.04.002

Millennium Ecosystem Assessment (MA). 2003. Ecosystems and human well-being: a framework for assessment. Island, Washington, D.C., USA. [online] URL: http://www.maweb. org

Millennium Ecosystem Assessment (MA). 2005a. Ecosystems and human well-being: synthesis. Island, Washington, D.C., USA. [online] URL: http://www.unep.org/maweb/documents/ document.356.aspx.pdf

Millennium Ecosystem Assessment (MA). 2005b. Ecosystems and human well-being: scenarios: findings of the Scenarios Working Group. Island, Washington, D.C., USA. [online] URL: http://www.maweb.org/en/Scenarios.aspx

Millennium Ecosystem Assessment in Biscay (EEMBiscay). 2010. The ecological footprint of Biscay. EEMBiscay project didactic sheets. $\mathrm{n}^{\mathrm{o}} 3$, UNESCO, Bilbao, Basque Country, Spain. [online] URL: http://www.ehu.es/cdsea/web/ecosistema/

Millennium Ecosystem Assessment in Biscay (EEMBiscay). 2012. Millennium Ecosystem Assessment in Biscay. Millennium Ecosystem Assessment in Biscay, Bilbao, Basque Country, Spain.

Narayan, D., R. Chambers, M. K. Shah, and P. Petesch. 1999. Global synthesis: consultations with the poor. World Bank, Washington, D.C., USA. [online] URL: http://www.fes.de/ cotonou/DocumentsEN/ThematicFocus/Poverty\%20Reduction/ GobalSynthesis_ConsultationsWithThePoor.pdf

Nelson G. C., E. Bennett, A. A. Berhe, K. G. Cassman, R. DeFries, T. Dietz, A. Dobson, A. Dobermann, A. Janetos, M. Levy, D. Marco, N. Nakicenovic, B. O’Neill, R. Norgaard, G. Petschel-Held, D. Ojima, P. Pingali, R. Watson, and M. Zurek. 2005. Drivers of change in ecosystem condition and services. Pages 173-222 in Millennium Ecosystem Assessment (MA). Ecosystems and human well-being: findings of the Scenarios Working Group. Island, Washington, D.C., USA. [online] URL: http://www.unep.org/maweb/documents/document.331. aspx.pdf
Nicholson, E., G. M. Mace, P. R. Armsworth, G. Atkinson, S. Buckle, T. Clements, R. M. Ewers, J. E. Fa, T. A. Gardner, J. Gibbons, R. Grenyer, R. Metcalfe, S. Mourato, M. Muûls, D. Osborn, D. C. Reuman, C. Watson, and E. J. Milner-Gulland. 2009. Priority research areas for ecosystem services in a changing world. Journal of Applied Ecology 46(6):1139-1144. http://dx.doi.org/10.1111/j.1365-2664.2009.01716.x

Olarieta, J. R., G. Besga, R. Rodríguez, A. Usón, M. Pinto, and S. Virgel. 1999. Sediment enrichment ratios after mechanical site preparation for Pinus radiata plantations in the Basque Country. Geoderma 93:255-267. http://dx.doi. org/10.1016/S0016-7061(99)00063-4

Palacios I., I. Casado-Arzuaga., X. Arana, and I. Madariaga. 2012. Millennium ecosystem assessment from the Basque Country. Pages 19-33 in I. Ayestarán and M. Onaindia, editors. Sustainable development, ecological complexity, and environmental values. Current Research Series 10, University of Nevada, Reno, Nevada, USA.

Palomo, I., B. Martín-López, C. López-Santiago, and C. Montes. 2011. Participatory scenario planning for protected areas management under the ecosystem services framework: the Doñana social-ecological system in southwestern Spain. Ecology and Society 16(1): 23. [online] URL: http://www. ecologyandsociety.org/vol16/iss1/art23/

Patel, M., K. Kok, and D. S. Rothman. 2007. Participatory planning in land use analysis: an insight into the experiences and opportunities created by stakeholder involvement in scenario construction in the northern Mediterranean. Land Use Policy 24:546-561. http://dx.doi.org/10.1016/j.landusepol.2006.02.005

Pereira, H. M., T. Domingos, C. Marta-Pedroso, V. Proença1, P. Rodrigues, M. Ferreira, R. Teixeira, R. Mota, and A. Nogal. 2009. Uma avaliação dos serviços dos ecossistemas em Portugal: cenários. Pages 709-711 in H. M. Pereira, T. Domingos, L. Vicente, and V. Proença1, editors. Ecossistemas e bem-estar humano: resultados da avaliação para Portugal do millennium ecosystem assessment. Escolar Editora, Lisboa, Portugal. [online] URL: http://ecossistemas.org/pt/relatorios. $\underline{\mathrm{htm}}$

Pereira, H. M., T. Domingos, and L. Vicente. 2006. Assessing ecosystem services at different scales in the Portugal millennium ecosystem assessment. Pages 59-80 in W. V. Reid, F. Berkes, T. Wilbanks, and D. Capistrano, editors. Bridging scales and knowledge systems: concepts and applications in ecosystem assessment. Island, Washington, D.C., USA. [online] URL: http://www.millenniumassessment.org/en/ Bridging.html

Pereira, E., C. Queiroz, H. M. Pereira, and L. Vicente. 2005. Ecosystem services and human well-being: a participatory study in a mountain community in Portugal. Ecology and 
Society 10(2): 14. [online] URL: http://www.ecologyandsociety. org/vol10/iss2/art14/

Perrings, C., A. Duraiappah, A. Larigauderie, and H. Mooney. 2011. The biodiversity and ecosystem services science-policy interface. Science 331:1139-1140. http://dx.doi.org/10.1126/ science. 1202400

Peterson, G. D., G. S. Cumming, and S. R. Carpenter. 2003. Scenario planning: a tool for conservation in an uncertain world. Conservation Biology 17:358-366. http://dx.doi. org/10.1046/j.1523-1739.2003.01491.x

Pretty, J. 2003. Social capital and the collective management of resources. Science 302:1912-1914. http://dx.doi. org/10.1126/science. 1090847

Quist, J.2007. Backcasting for a sustainable future: the impact after ten years. Dissertation. Delft Technical University, Delft, Netherlands. [online] URL: http://repository.tudelft.nl/view/ ir/uuid\%3Abd642b6a-17c7-4284-8be7-10be10dc336c/

Quist, J., and P. Vergragt. 2006. Past and future of backcasting: the shift to stakeholder participation and a proposal for a methodological framework. Futures 38:1027-1045. http://dx. doi.org/10.1016/j.futures.2006.02.010

Reed, M. S. 2008. Stakeholder participation for environmental management: a literature review. Biological Conservation 141:2417-2431. http://dx.doi.org/10.1016/j.biocon.2008.07.014

Ribot, J. C. 2002. Democratic decentralization of natural resources: institutionalizing popular participation. World Resources Institute, Washington, D.C., USA. [online] URL: http://pdf.wri.org/ddnr_full_revised.pdf

Robinson, J. 2003. Future subjunctive: backcasting as social learning. Futures 35:839-856. http://dx.doi.org/10.1016/ $\underline{\text { S0016-3287(03)00039-9 }}$

Rodríguez, J. P., T. D. Beard, Jr., E. M. Bennett, G. S. Cumming, S. Cork, J. Agard, A. P. Dobson, and G. D. Peterson. 2006. Trade-offs across space, time, and ecosystem services. Ecology and Society 11(1): 28. [online] URL: http://www. ecologyandsociety.org/vol11/iss1/art28/

Sala, O. E., D. P. van Vuuren, H. M. Pereira, D. Lodge, J. Alder, G. Cumming, A. Dobson, V. Wolters, M. A. Xenopoulos, A. S. Zaitsev, M. G. Polo, I. Gomes, C. Queiroz, and J. A. Rusak. 2006. Biodiversity across scenarios. Pages 375-408 in Millennium Ecosystem Assessment. Ecosystems and human well-being: findings of the Scenarios Working Group. Island, Washington, D.C., USA. [online] URL: http:// www.unep.org/maweb/documents/document.334.aspx.pdf

Santos, T., J. L. Telleria, M. Díaz, and R. Carbonell. 2006. Evaluating the benefits of CAP reforms: can afforestations restore bird diversity in Mediterranean Spain? Basic and Applied Ecology 7:483-495. http://dx.doi.org/10.1016/j. baae.2005.11.001
Scholes, R. J., and R. Biggs. 2004. Ecosystem services in southern Africa: a regional assessment. Council for Scientific and Industrial Research (CSIR), Pretoria, South Africa.

Schultz, L., C. Folke, and P. Olsson. 2007. Enhancing ecosystem management through social-ecological inventories: lessons from Kristianstads Vattenrike, Sweden. Environmental Conservation 34:140-152. http://dx.doi.org/10.1017/ $\underline{\mathrm{S} 0376892907003876}$

Shearer, A. W. 2005. Approaching scenario-based studies: three perceptions about the future and considerations for landscape planning. Environment and Planning B: Planning and Design 32:67-87. http://dx.doi.org/10.1068/b3116

Shuman, S. P. 1996. The role of facilitation in collaborative groups. Pages 126-140 in C. Huxham, editor. Creating collaborative advantage. Sage, Thousand Oaks, California, USA.

Stringer, L. C., A. J. Dougill, E. Fraser, K. Hubacek, C. Prell, and M. S. Reed. 2006. Unpacking "participation" in the adaptive management of social-ecological systems: a critical review. Ecology and Society 11(2): 39. [online] URL: http:// www.ecologyandsociety.org/vol11/iss2/art39/

Sub-Global Assessment Network (SGA Network). 2011. SubGlobal Assessment Network 3rd Annual Meeting Report. United Nations Environment Programme/World Conservation Monitoring Centre, Cambridge, UK. [online] URL: http:// www.ecosystemassessments.net/news/87-3rd-sga-network-annualmeeting-report.html

Termorshuizen, J. W., and P. Opdam. 2009. Landscape services as a bridge between landscape ecology and sustainable development. Landscape Ecology 24:1037-1052. http://dx.doi.org/10.1007/s10980-008-9314-8

The World Café. 2012. About the World Café and The World Café Community Foundation. The World Café. [online] URL: http://www.theworldcafe.com/about.html

van Asselt, M. B. A., and N. Rijkens-Klomp. 2002. A look in the mirror: reflection on participation in integrated assessment from a methodological perspective. Global Environmental Change 12:167-184. http://dx.doi.org/10.1016/S0959-3780 (02)00012-2

Van Berkel, D. B., S. Carvalho-Ribeiro, P. H. Verburg, and A. Lovett. 2011. Identifying assets and constraints for rural development with qualitative scenarios: a case study of Castro Laboreiro, Portugal. Landscape and Urban Planning 102 (2):127-141. http://dx.doi.org/10.1016/j.landurbplan.2011.03.016

Vergragt, P. J., and J. Quist. 2011. Backcasting for sustainability: introduction to the special issue. Technological Forecasting and Social Change 78:747-755. http://dx.doi. org/10.1016/j.techfore.2011.03.010 
Weighell, T. 2011. UK dependence on non-UK ecosystem services. Pages 1045-1065 in UK national ecosystem assessment. The UK national ecosystem assessment technical report. United Nations Environment Programme/World Conservation Monitoring Centre, Cambridge, UK.

Whitfield, S., H. J. Geist, and A. A. R. Ioris. 2011. Deliberative assessment in complex socioecological systems: recommendations for environmental assessment in drylands. Environmental Monitoring and Assessment 183:465-483. http://dx.doi. org/10.1007/s10661-011-1933-X

Wollenberg, E., D. Edmunds, and L. Buck. 2000. Using scenarios to make decisions about the future: anticipatory learning for the adaptive co-management of community forests. Landscape and Urban Planning 47:65-77. http://dx. doi.org/10.1016/S0169-2046(99)00071-7

Zurek, M. B., and T. Henrichs. 2007. Linking scenarios across geographical scales in international environmental assessments. Technological Forecasting and Social Change 74:1282-1295. http://dx.doi.org/10.1016/j.techfore.2006.11.005 
APPENDIX 1. Agenda of the workshops.

Agenda of the first workshops: 17th June 2010

$8.30-9.00 \quad$ Registration of participants and working group assignment.

$9.00-9.30$ Introductions to the workshops: Context, objectives and expected results.

$9.30-9.45 \quad$ Methodologies of the workshops and next activity explanation.

9.45- 10.45 Discussions in working groups: Identification, description and selection of key drivers of change.

10.45-11.15 Plenary session: Presentation of the results of the working groups and development of a common list of drivers of change.

$11.15-11.45$ Coffee break with organic food and fair trade products.

$11.45-13.30$ Discussions in working groups: From MA global scenarios to Biscay scenarios.

$13.30-14.30 \quad$ Collective lunch.

$14.30-15.00 \quad$ Plenary session: Presentation by participants of the developed scenarios for Biscay and explanation of next steps towards a target scenario.

$15.00-17.00$ Discussions in working groups: Scenario characterization in terms of the provision of ecosystem services and human well-being.

$17.00-17.30 \quad$ Plenary session: Presentation of the group's results in a common mural. 
Agenda of the second workshops: 18th June 2010

$9.00-9.30 \quad$ Welcome, first workshop summary and methodology explanation.

$9.30-10.15$ Identification of desired and undesired aspect for the future scenario starting up with the results of Biscay scenarios characterization.

$10.15-11.00$ Target scenario selection and description.

$11.00-13.30$ Work Café: Definition of management strategies that can lead to a desirable future for Biscay social ecological system.

$13.30-14.30 \quad$ Collective lunch.

$14.30-16.30$ Continuation to the Work Café: Definition of management strategies that can lead to a desirable future for Biscay social ecological system.

$16.30-17.00 \quad$ Plenary session: Work café results sharing.

$17.00-17.30 \quad$ General conclusions and closing session. 
APPENDIX 2. Results from the questionnaires.

Table A2.1. Main results from questionnaires that were handed out after workshops.

\begin{tabular}{|l|c|c|c|}
\cline { 2 - 4 } \multicolumn{1}{l|}{} & Yes & No & $\begin{array}{c}\text { More or } \\
\text { less }\end{array}$ \\
\hline Were you clear on the purpose of the workshop before the event? & $11.11 \%$ & $22.22 \%$ & $66.67 \%$ \\
\hline Are you clear now? & $94.44 \%$ & $0 \%$ & $5.56 \%$ \\
\hline Did you feel that you could express your opinion freely? & $100 \%$ & $0 \%$ & \\
\hline $\begin{array}{l}\text { Did the outcome of your scenario group reflect the opinions of everyone in } \\
\text { your group? }\end{array}$ & $77.78 \%$ & $22.22 \%$ & \\
\hline Would you like to participate in a follow-up workshops? & $100 \%$ & $0 \%$ & $0 \%$ \\
\hline
\end{tabular}

Fig. A2.1: Importance and potential for successful intervention for the different indirect drivers analyzed in the questionnaire completed by participants before the workshops. The importance is measured as the percentage of respondent that value each indirect driver of high importance $(=1)$ or important $(=2)$; whereas potential for successful intervention is measured as the percentage of respondent that reported a high $(=1)$ or medium $(=2)$ potential for successful intervention from Biscay for each of the studied indirect driver.

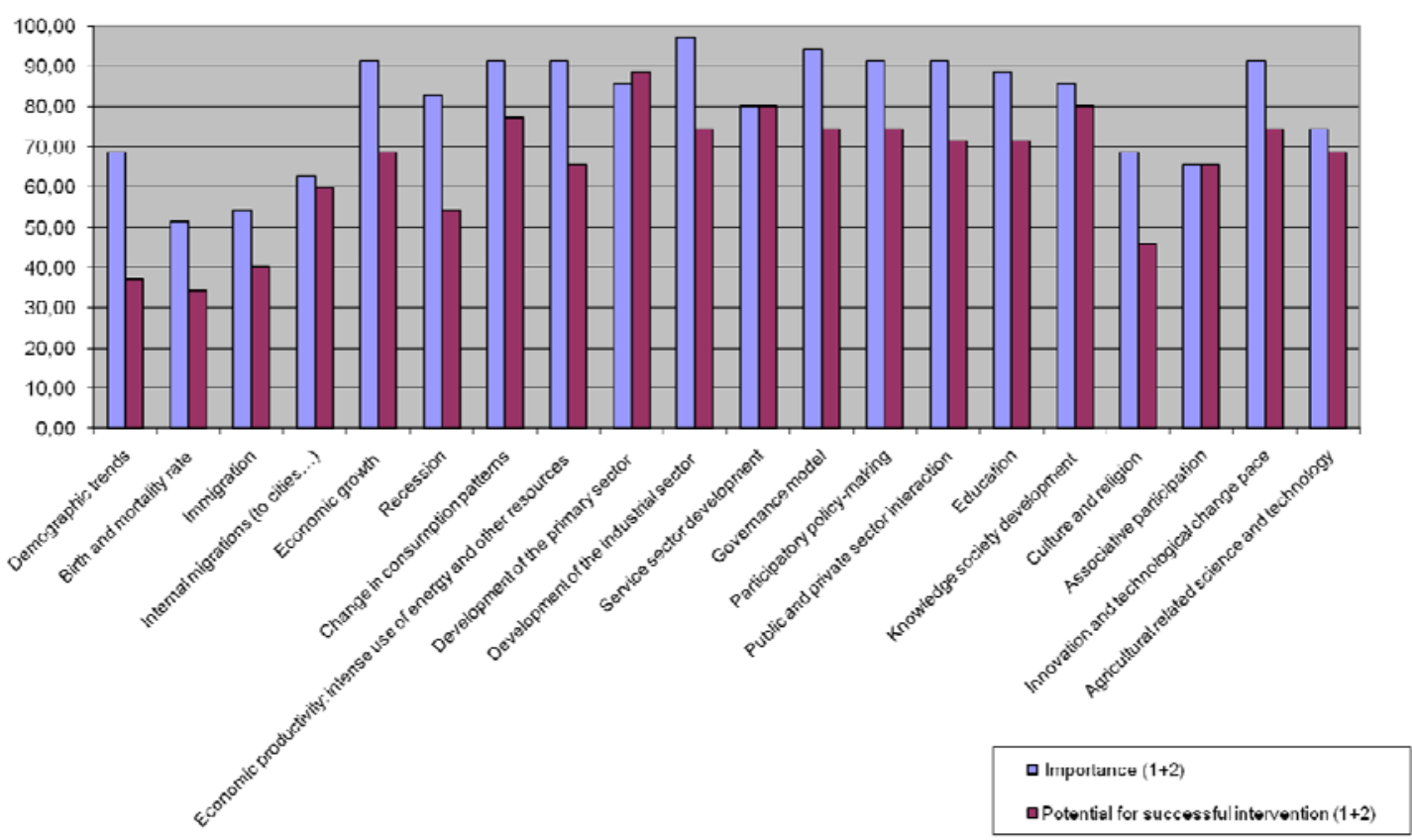


Fig. A2.2: Importance and potential for successful intervention of the different direct drivers analyzed in the questionnaire completed by participants before the workshops. The importance is measured as the percentage of respondent that value each indirect driver of high importance $(=1)$ or important $(=2)$; whereas potential for successful intervention is measured as the percentage of respondent that reported a high $(=1)$ or medium $(=2)$ potential for successful intervention from Biscay for each of the studied indirect driver.

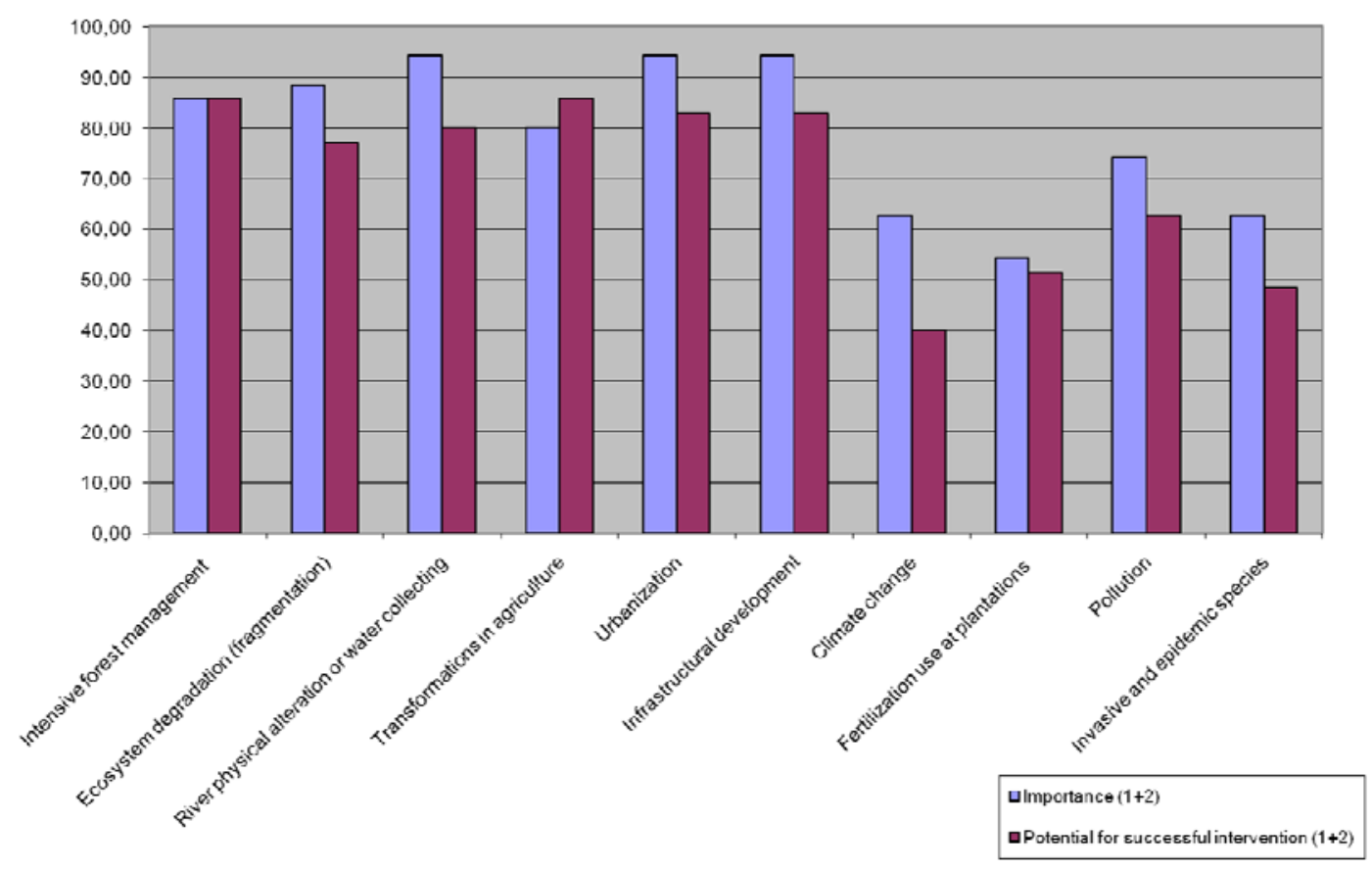

